NBSIR 81-2221

\title{
Experimentally Determined Performance of Some Residential Circuit Breakers
}

Robert W. Beausoliel

William J. Meese

Center for Building Technology National Engineering Laboratory U.S. Department of Commerce National Bureau of Standards Washington, DC 20234

April 1981

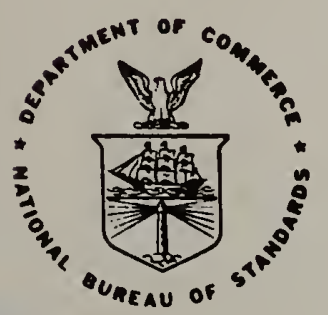

I.S. DEPARTMENT OF COMMERCE

.456 ATIONAL BUREAU OF STANDARDS

$81-2221$

1981

c. 2 

Robert W. Beausoliel

William J. Meese

Center for Building Technology National Engineering Laboratory U.S. Department of Commerce National Bureau of Standards Washington, DC 20234

April 1981

U.S. DEPARTMENT OF COMMERCE, Malcolm Baldrige, Secretary NATIONAL BUREAU OF STANDARDS, Ernest Ambler, Director 


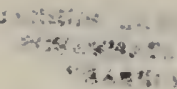

- $\because \div \div$ 


\section{ABSTRACT}

Laboratory test results show that at low ambient temperatures some residential-type circuit breakers may not trip at currents up to 140 percent of rated currents. Under some environmental conditions this may lead to wiring temperatures that exceed the limitations specified in the National Electrical Code. The results also show that circuits sometimes open at the point of short circuits before circuit breakers operate. Ignition of combustibles proximate to the point of such short circuits sometimes occurs.

The results indicate the need for a more detailed study of overcurrent protection performance in the field and under laboratory conditions. Also needed are the development of more meaningful scientific/mathematical principles and models on the functional characteristics of circuit breakers.

Key Words: branch circuits; circuit breaker; electrical fire; low ambient temperature; trip time. 
In view of the present accepted practice in this country for building technology, common U.S. units of measurement have been used throughout this document. In recognition of the position of the United States as a signatory to the General Conference on Weights and Measures, which gave official status to the metric SI system of units in 1960, assistance is given to the reader interested in making use of the coherent system of SI units by giving conversion factors applicable to U.S. units used in this document.

Mass 1 pound-mass $\left(1 b_{m}\right)=0.453592 \mathrm{Kg}$

Length 1 inch $=0.0254$ meter $(\mathrm{m})$

Temperature $t$ (Celsius) $=5 / 9[t($ Fahr $)-32]$

Torque .1 Lbf.in $=0.113$ newton meter $(\mathrm{N} \bullet \mathrm{m})$

Time 1 hour $=60$ minutes $=3,600$ seconds 
1. INTRODUCTION $\ldots \ldots \ldots \ldots \ldots \ldots \ldots \ldots \ldots \ldots \ldots \ldots \ldots \ldots \ldots \ldots \ldots \ldots \ldots \ldots$

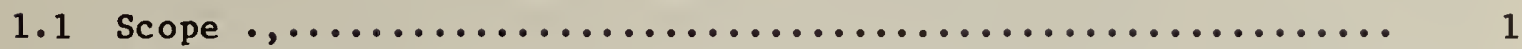

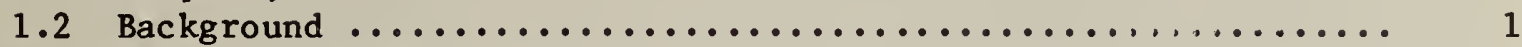

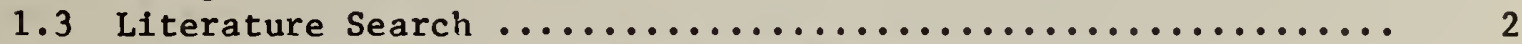

1.4 Functional Description of a Thermal Magnetic Circuit

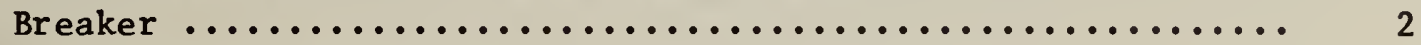

2. CIRCUIT BREAKER PERFORMANCE WITH SLIGHT TO MODERATE

OVERCURRENTS AT VARIOUS AMBIENT TEMPERATURES ............... 5

2.1 Circuit Breaker/Temperature Test Setup and Test Procedure ... 5

2.2 Test Results for Single Circuit Breakers .............. 7

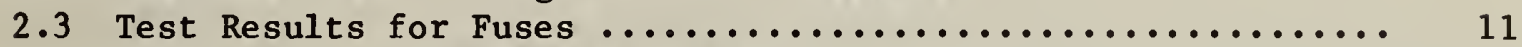

2.4 Multi-Circuit Breaker Test Results .................. 20

3. CIRCUIT BREAKER PERFORMANCE UNDER SHORT-CIRCUIT CONDITIONS ...... 24

3.1 Short-Circuit Test Setup and Test Procedure ............. 24

3.2 Test Results $\ldots \ldots \ldots \ldots \ldots \ldots \ldots \ldots \ldots \ldots \ldots \ldots \ldots \ldots \ldots \ldots \ldots \ldots . \ldots \ldots$

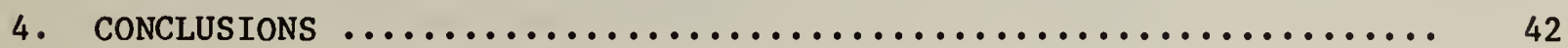

5. RECOMMENDATIONS ................................ 42

6. REFERENCES $\ldots \ldots \ldots \ldots \ldots \ldots \ldots \ldots \ldots \ldots \ldots \ldots \ldots \ldots \ldots \ldots \ldots \ldots \ldots \ldots$ 



\section{INTRODUCTION}

The National Electrical Code (NEC) [1]* states that a circuit breaker is a device designed to open and close a circuit by nonautomatic means through manual operation of the device and to open the circuit automatically at or beyond a predetermined overcurrent without damage to itself or to protected electrical circuits when properly applied within its rating. An overcurrent is defined as any current in excess of the rated current of equipment conductors. Overcurrents may result from overloads, short circuits, or ground faults [1].

\subsection{SCOPE}

This investigation presents results from laboratory testing of residential type, single-pole, $20 \mathrm{~A}$, thermal-magnetic circuit breakers. Standard $20 \mathrm{~A}$ plug fuses were tested for comparison with circuit breaker performance.

\subsection{BACKGROUND}

The need for circuit breaker research became apparent during recent investigations of temperatures produced by self-heating of wiring when surrounded by thermal insulation [2]. During that investigation it was recognized that circuit breakers do not quickly open circuits that are subjected to overcurrents. Circuit breakers are widely utilized in buildings because of the simplicity of resetting following operation on overloaded circuits without replacement, as in the case of fuses.

The Underwriters' Laboratories Standard, UL 489, for molded-case circuit breakers requires circuit breakers to open circuits within one hour at 135 percent of their rated current [3]. The UL standard requires this onehour performance with an ambient temperature of $25^{\circ} \mathrm{C}\left(77^{\circ} \mathrm{F}\right)$. The standard does not include criteria for lower ambient air temperatures. The National Electrical Manufacturers Association (NEMA) standard for molded-case circuit breakers considers circuit breaker operation at under $0^{\circ} \mathrm{C}$ ambient temperature as unusual service conditions that should be brought to the attention of the manufacturer [4]. The standard does not present details concerning circuit breaker performance at $0^{\circ} \mathrm{C}$ or below.

A further impetus for circuit breaker research was provided during NBS laboratory short circuit experimentation with branch circuit wiring systems. It was observed that circuit breakers did not always open during short circuits. It was found that the circuits opened at a contact interface such as that between the circuit conductor and a shorting nail. The opening of the circuit in this manner was often accompanied by the expulsion of molten metal particles from the nail and/or conductor interface. Such performance might cause ignition of proximate combustibles. Neither the literature nor the circuit breaker standards appear to address this type of circuit breaker performance per se.

* References cited at end of text. 


\subsection{LITERATURE SEARCH}

A search of the technical 1iterature revealed a UL Bulletin of Research [5] which addresses ambient temperature effects on circuit breakers. UL research was carried out because field reports to UL indicated that overcurrent devices sometimes failed to open circuits when subjected to moderate overloads and low ambient temperatures. The UL Bulletin as 1 isted in reference [5] showed that both circuit breakers and plug fuses of 15 A rating oftentimes did not open the test circuits when tested at 135 percent of rated current at ambient temperatures of $32,0,-10,-20$, and $-30^{\circ} \mathrm{F}$. The UL Bulletin does not have a conclusion section per se [5]; however, the abstract states the following:

"These findings confirm a view previously held that thermally operated devices are affected by the ambient temperature at which they are operated, and this should be taken into account in actual practice."

The UL circuit breaker and plug fuse tests were carried out over thirty years ago; NBS found no recent tests reported in the literature. The NBS tests presented in this report were carried out to gain insight into the low temperature performance of modern residential single-pole circuit breakers.

The literature search did not reveal studies concerning residential circuit breaker performance during short circuits. The literature contained very little information concerning the scientific/mathematical principles of residential circuit breakers; mathematical models for these breakers were not found in the literature.

\subsection{FUNCTIONAL DESCRIPTION OF A THERMAL-MAGNETIC CIRCUIT BREAKER}

Residential circuit breakers are usually of the molded-case type. A molded-case circuit breaker is one that is assembled as an integral unit in a housing of molded insulating materials [6]. The typical molded-case circuit breaker is equipped with both time-delay and instantaneous tripping devices [6].

Time-delay tripping has inverse time characteristics. This means that as the overload increases, the tripping time decreases. This results in the following performance.

a. The circuit breaker accepts short-duration overloads for motor starting.

b. During a large overcurrent or a short circuit, the circuit breaker is intended to trip rapidly to protect circuit conductors and electrical insulation from overheating.

The NEC defines several terms applying to circuit breakers [1]. These are as follows: 
a. Adjustable: A qualifying term indicating that the circuit breaker can be set to trip at various values of current and/or time within a pre-determined range.

b. Instantaneous Trip: A qualifying term indicating that no delay is purposely introduced in the tripping action of the circuit breaker.

c. Inverse Time: A qualifying term indicating there is purposely introduced a delay in the tripping action of the circuit breaker, which delay decreases as the magnitude of the current increases.

d. Nonadjustable: A qualifying term indicating that the circuit breaker does not have any adjustment to alter the value of current at which it will trip or the time required for its operation.

e. Setting: The value of current and/or time at which an adjustable circuit breaker is set to trip.

Most residential circuit breakers of $15 \mathrm{~A}$ and $20 \mathrm{~A}$ size are single pole, inverse time, and nonadjustable. Residential circuit breakers of this size usually operate by thermal-magnetic means. The operation of a thermal magnetic breaker is depicted in figure 1 [7], which shows the release or tripping element. The element consists of a thermal, bimetallic element to which a magnetic plate has been added. During slight overcurrents, the magnetic force produced by the magnetic plate is so slight that it contributes little force to trip the circuit breaker, and the circuit breaker trips primarily because of the force generated by the heating of the bimetallic element. With high short-circuit currents, the magnetic tripping force predominates. 


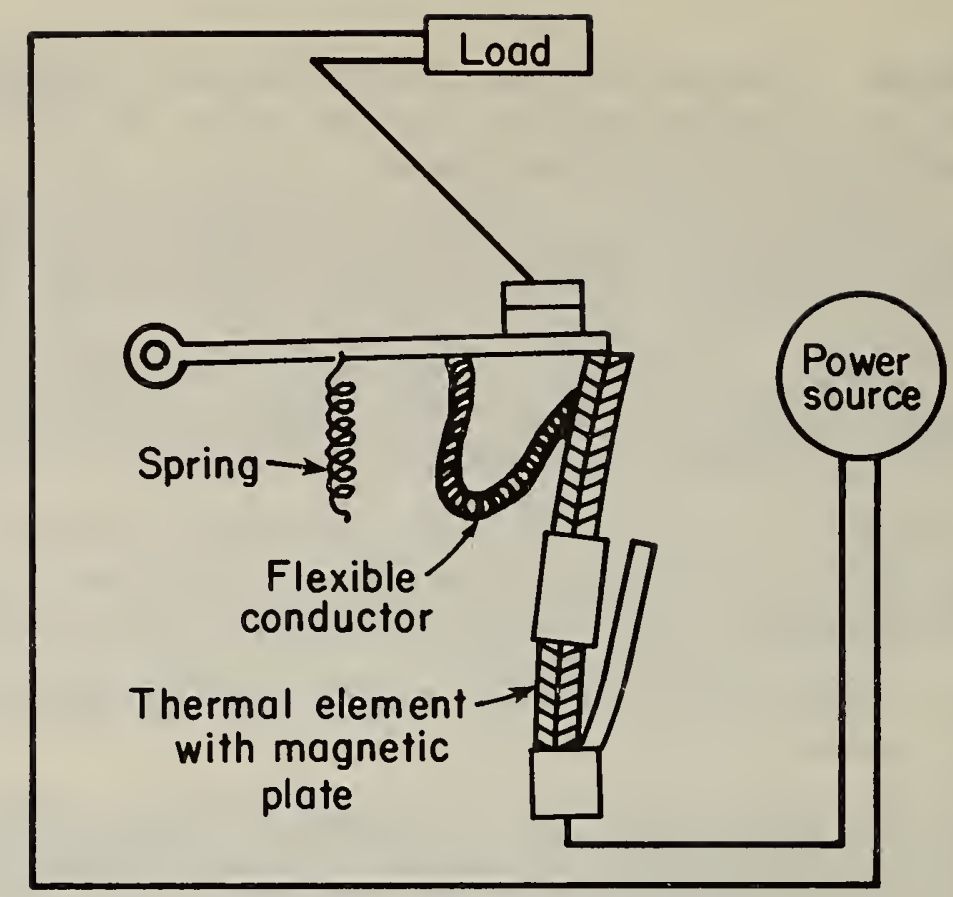

I Normal load condition

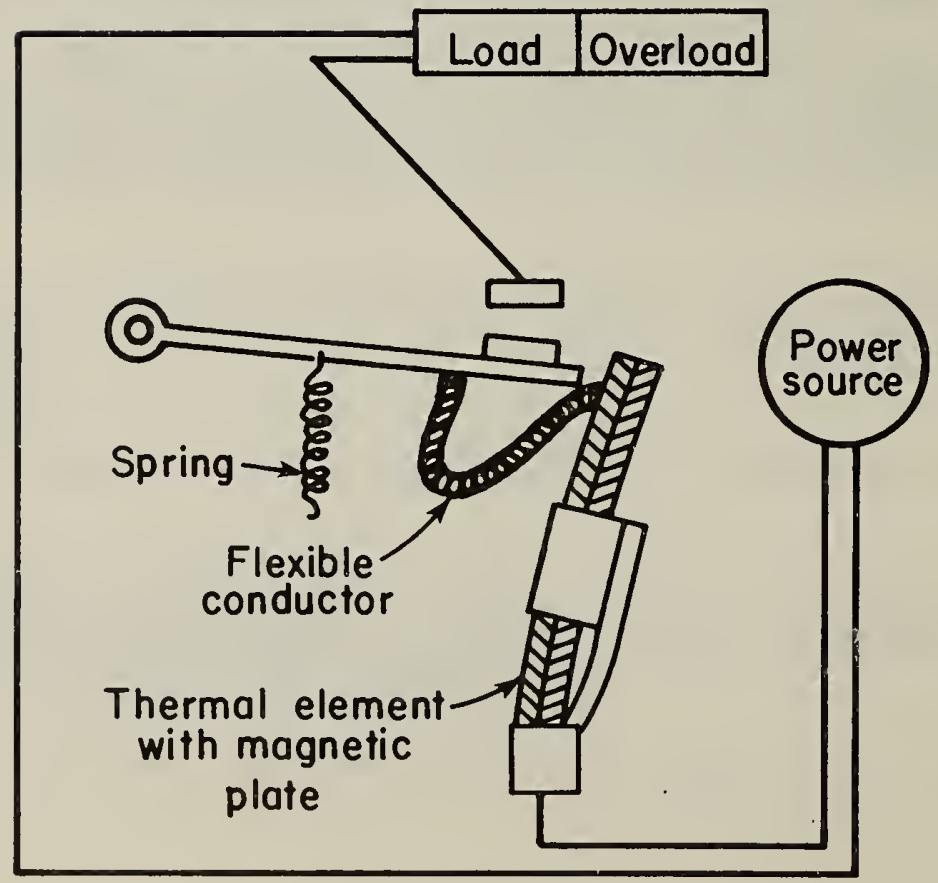

II Overload

Figure 1. Principle of thermal-magnetic breaker [7] 


\section{CIRCUIT BREAKER PERFORMANCE WITH SLIGHT TO MODERATE OVERCURRENTS AT VARIOUS AMBIENT TEMPERATURES}

The purpose of the investigation reported upon in this section is to determine whether or not circuit breakers will trip during overcurrents when the circult breaker is located in cool ambient air, such as might exist in a basement.

\subsection{CIRCUIT BREAKER/TEMPERATURE TEST SETUP AND TEST PROCEDURE}

The test setup shown in figure 2 consisted of the following:

a. The four-circuit breaker load center was of a type suitable for service entrance usage. The 20 A circuit breakers were wired with \#12 AWG solid copper TW insulated wire ${ }^{l}$.

b. The measuring junction of a copper/constantan (type $T$ ) thermocouple formed from $0.020-1$ nch diameter thermocouple wire was placed in contact with the circuit breaker wire binding screw.

c. The thermocouple output was read on a digital voltmeter.

d. The reference junction of the thermocouple was maintained at $32^{\circ} \mathrm{F}$ in a Dewar containing a mixture of ice and water.

The millivolt thermocouple readings were converted to temperature in degrees Fahrenheit based on NBS Monograph 125 [8].

e. Low voltage current was impressed on the circuit breaker or fuse by means of a current controller, a motor-driven autotransformer, and a 5 KVA step-down transformer having a $120 \mathrm{~V}$ primary winding and a $12 \mathrm{~V}$ secondary winding.

f. Current was measured by recording the voltage drop across a $0.001 \mathrm{ohm} \pm 0.05 \%, 500 \mathrm{~A}, \mathrm{AC}$ shunt.

g. The digital voltmeter was connected to a double-pole double-throw toggle switch for measuring either circuit breaker temperature or current.

h. The circuit breaker or fuse and load centers were placed in their normal wall-mounted position within a small environmental chamber having a temperature range capability of $+350^{\circ} \mathrm{F}$ to $-120^{\circ} \mathrm{F}$ with a specified control tolerance of $\pm 1 / 4^{\circ} \mathrm{F}$. The work space was 16 inches wide, 12 inches high, and 11 inches deep. The chamber had its own temperature indicator.

$1 \mathrm{TW}$ wire insulation has a $60^{\circ} \mathrm{C}$ maximum operating temperature rating 


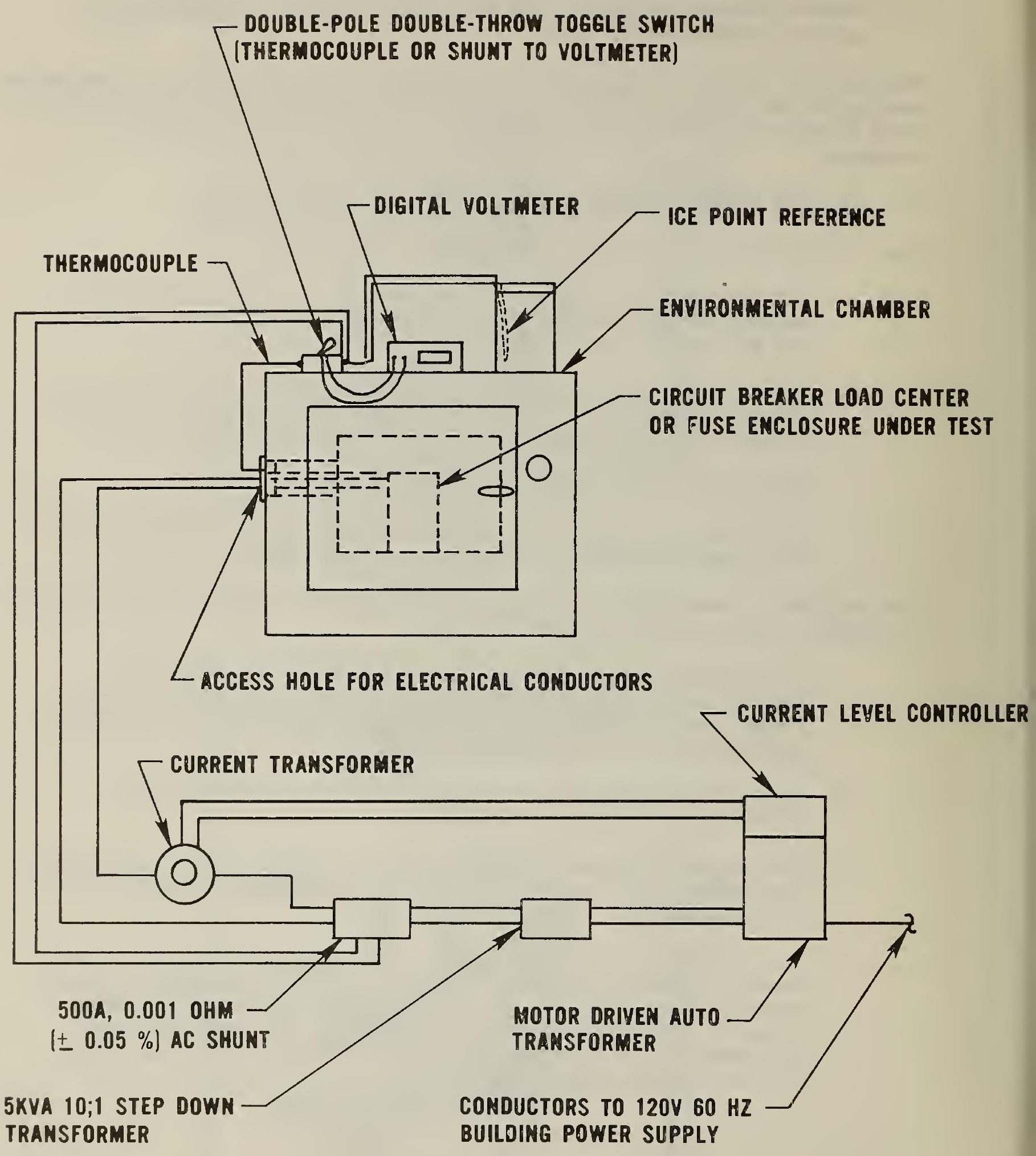

Figure 2. Test setup for temperature performance of breakers and fuses 
1. Electric timers were used for timing overcurrent device trips. In case of very fast trips a storage-type oscilloscope was connected across the AC shunt mentioned in ( $f$ ) above.

The test procedure consisted of the following:

a. Single-pole, $20 \mathrm{~A}$, molded-case circuit breakers of two manufacturers were used in this work. (See table 1). Three of these breakers had been used in other tests involving several hundred short circuits with currents in excess of $500 \mathrm{~A}$ rms (root mean square), with a building supply voltage of 118 volts. Other breakers were new (as received from the vendor).

b. The autotransformer was adjusted for proper current setting.

c. When the temperature established within the environmental chamber was measured on the wire binding screw of the circuit breaker, the current was impressed on the breaker and the timer was started. When the breaker tripped, the timer was shut off, recording the time to trip.

The test setup of figure 2 was for only one circuit breaker or one fuse. It is conceivable that a residence may have only one circuit operating at a given time. However, circuit-breaker load centers usually involve combinations of breakers, some carrying current and some not. Current-carrying breakers and wiring contribute heat to the circuit breaker load center, which elevates the temperatures of other breakers. The test setup of figure 3 was used for determining the influence of heat from additional breakers on breaker tripping performance. The load center containing three breakers was mounted in the chamber shown in figure 2. The load center was identical to that used in figure 2. The setup of figure 3 uses an additional autotransformer, stepdown transformer, $0.001 \mathrm{ohm} \mathrm{AC}$ shunt and digital meter to measure and control current in the circuit breaker specimens 非 5 and $\|^{6}$. Circuit breaker specimens \#5 and $\# 6$ were operated at 0-18 A in order to supply additional heat and observe whether breaker 非 1 would trip when subjected to $27 \mathrm{~A}$ with relatively low ambient air temperature. Temperature was measured only on breaker 非 The voltage drops across circuit breakers and currents through them were used to indicate the heating effect of each breaker.

\subsection{TEST RESULTS FOR SINGLE CIRCUIT-BREAKERS}

Circuit breaker specimen 非 1 was tested over the temperature and current range shown in table 2 . Since circuit breaker 非 1 did trip satisfactorily over the range of temperature and currents of table 2, the breaker was subjected to other currents and temperatures, presented in table 3 . As this test shows, the breaker usually did not trip. Run number 6 was a check on breaker performance at 135 percent of rated current similar to the calibration test in UL Standard 489 [3]. The breaker passed this calibration test. At the end of the 4.5-hour run 8 in table 3 , the current was increased to $28 \mathrm{~A}$, shown in the table as run $\|^{9}$. At the end of run 1 9 without the circuit 


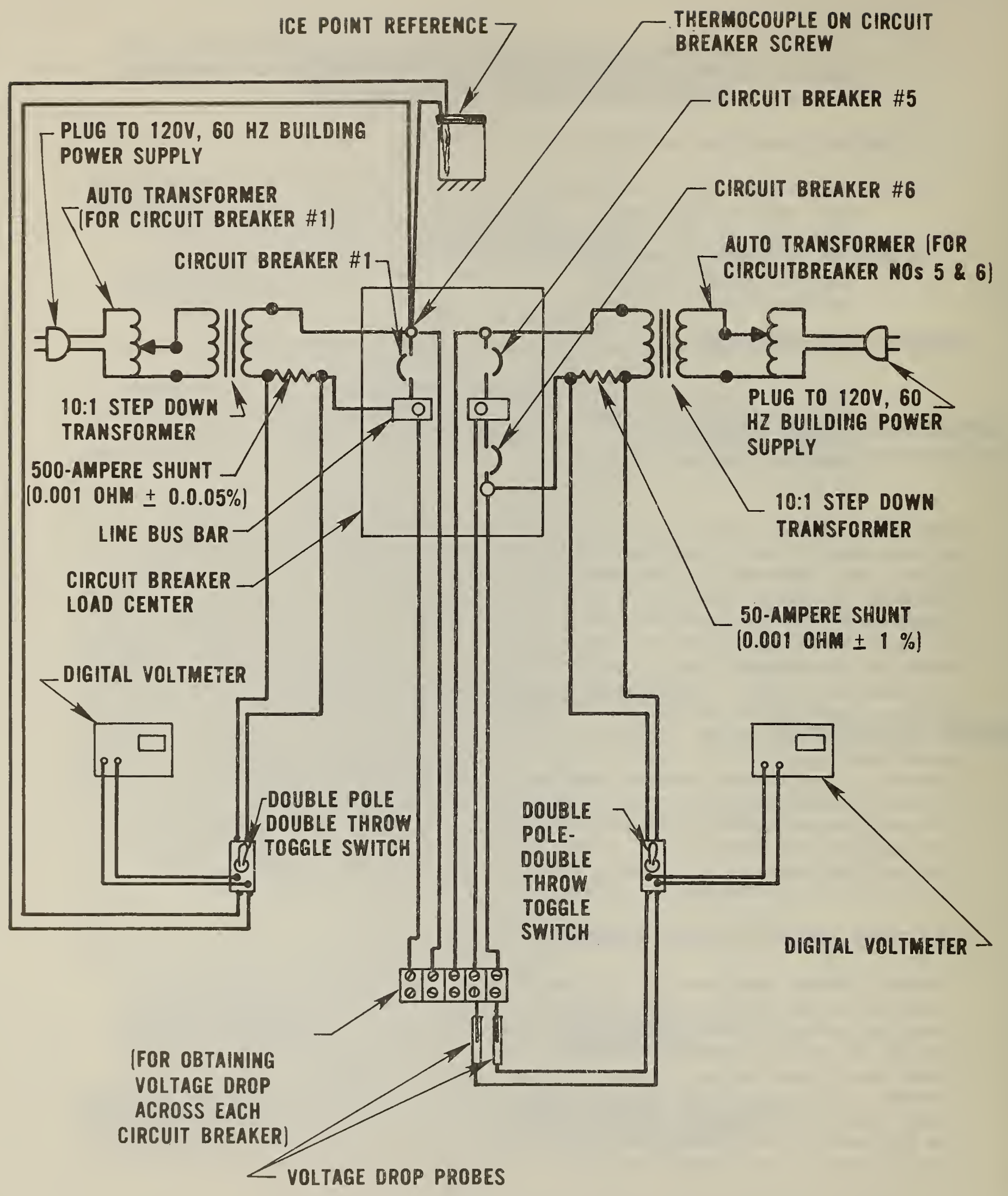

Figure 3. Multi-circuit-breaker test setup 
TABLE 1. Circuit Breaker and Fuse Test Specimen

\begin{tabular}{|c|c|c|c|c|}
\hline Circuit Breakers: & $\frac{\text { Manuf }}{\text { Spec }}$ & $\frac{\text { cturer A }}{\text { men No. }}$ & $\frac{\text { Manuf }}{\text { Spec }}$ & $\frac{\text { cturer B }}{\text { men No. }}$ \\
\hline 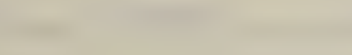 & 1 & (used) & 6 & (new) \\
\hline & 2 & " & 7 & " \\
\hline & 3 & $"$ & 8 & $"$ \\
\hline & 4 & (new) & 9 & $"$ \\
\hline & 5 & $"$ & & \\
\hline
\end{tabular}

Fuses: 30 standard $20 \mathrm{~A}$ plug fuses of one manufacturer.

TABLE 2. Performance of Circuit Breaker 非 Over Extreme Temperature Range

\section{AMBIENT AIR TEMPERATURE \\ AND CIRCUIT BREAKER TRIP TIME - SEC:}

\begin{tabular}{|c|c|c|c|c|c|c|c|c|c|c|c|}
\hline RUN & & $150^{\circ} \mathrm{F}$ & $104^{\circ} \mathrm{F}$ & $77^{\circ} \mathrm{F}$ & $50^{\circ} \mathrm{F}$ & $32^{\circ} \mathrm{F}$ & $0^{\circ} \mathrm{F}$ & $-10^{\circ} \mathrm{F}$ & $-20^{\circ} \mathrm{F}$ & $-30^{\circ} \mathrm{F}$ & $-40^{\circ} \mathrm{F}$ \\
\hline 1 & $70 \mathrm{~A}$ & 3.85 & 5.3 & 6.0 & 6.8 & 8.3 & 8.4 & 9.4 & 9.9 & 12.0 & 17.0 \\
\hline 2 & & 3.89 & 5.84 & 6.1 & 6.6 & 8.6 & 9.4 & 9.8 & 11.9 & 11.3 & 17.8 \\
\hline 4 & $60 A$ & 4.7 & 8.20 & 9.2 & 10.4 & 12.7 & 14.3 & 14.7 & 15.0 & 16.0 & 17.5 \\
\hline 5 & & 5.8 & 7.7 & 8.0 & 10.7 & 12.9 & 14.2 & 15.5 & 16.0 & 17.7 & 17.0 \\
\hline 5 & $50 A$ & 7.2 & 12.0 & 14.2 & 16.5 & 23.9 & 26.7 & 27.6 & 29.2 & 27.7 & 30.0 \\
\hline 6 & & 7.1 & 11.76 & 14.8 & 16.9 & 24.5 & 27.8 & 27.8 & 32.7 & 28.0 & 30.0 \\
\hline 7 & $40 \mathrm{~A}$ & 11.9 & 22.0 & 30.0 & 42.7 & 54.8 & 81.6 & 80.3 & 32.7 & 99.4 & 125.8 \\
\hline 8 & & 12.0 & 22.8 & 28.9 & 37.4 & 57.5 & 105 & 76.0 & 193 & 90.8 & 126.8 \\
\hline 9 & $27 \mathrm{~A}$ & 59.7 & 24.24 & 76.8 & & & & & & & \\
\hline 10 & & 34.5 & 34.3 & 406 & & & & & & & \\
\hline
\end{tabular}


TABLE 3. Test of Circuit Breaker \#1 Over the Current Range 24 A to 29 A Within the Temperature Range

$36^{\circ} \mathrm{F}$ to $77^{\circ} \mathrm{F}$

\begin{tabular}{cccccc}
\hline & $\begin{array}{c}\text { Ambient } \\
\text { Temperature } \\
{ }^{\circ} \mathrm{F}\end{array}$ & $\begin{array}{c}\text { Current } \\
\text { Amperes }\end{array}$ & Trip & Hours & Seconds \\
\hline 1 & 39 & 25 & No & 3.5 & \\
2 & 36 & 27 & No & 3.5 & \\
3 & 41 & 27 & No & 6.7 & 972 \\
4 & 50 & 27 & No & 5.5 & \\
\hline 5 & 60 & 27 & No & 5.0 & \\
\hline 7 & 77 & 27 & Yes & & \\
\hline $8 *$ & 77 & 24 & No & 1.5 & \\
\hline $9 *$ & 61 & 27 & No & 4.5 & \\
\hline $10 *$ & 61 & 28 & No & 2.5 & \\
\hline
\end{tabular}

* consecutive runs 
breaker tripping, the current was increased to $29 \mathrm{~A}$. As shown, the circuit breaker tripped in 10 seconds.

Circuit breaker $\# 2$ was tested over the temperature range $39^{\circ} \mathrm{F}$ to $77^{\circ} \mathrm{F}$ and at currents of $25 \mathrm{~A}$ and $27 \mathrm{~A}$, as shown in table 4. The circuit breaker tripped during all runs.

Circuit breaker 非 was tested over the temperature range $49^{\circ} \mathrm{F}$ to $77^{\circ} \mathrm{F}$ and the current range from $27 \mathrm{~A}$ to $40 \mathrm{~A}$. Results are shown in table 5. The circuit breaker did not trip at $27 \mathrm{~A}$ and $49^{\circ} \mathrm{F}$ during one run out of three. During the one run at $25 \mathrm{~A}$ and $49^{\circ} \mathrm{F}$, the circuit breaker did not trip. The circuit breaker did not trip during the run at $24 \mathrm{~A}$ and $59^{\circ} \mathrm{F}$. During one run at $25 \mathrm{~A}$ and $77^{\circ} \mathrm{F}$, the circuit breaker tripped; during a following run at $25 \mathrm{~A}$ and $78^{\circ} \mathrm{F}$ the circuit breaker did not trip.

Results for circuit breaker 非 are shown in table 6 . The circuit breaker did not trip during runs $\$ 7$ and $\$ 9$ at $27 \mathrm{~A}$ and $45^{\circ} \mathrm{F}$ ambient temperature. However, during run 8 when the current was increased by one ampere to $28 \mathrm{~A}$, the circuit breaker tripped in 591 seconds.

Circuit breaker specimens 5 and 1 were spot checked at $27 \mathrm{~A}$ and $45^{\circ} \mathrm{F}$. These circuit breakers did not trip during 6-hour runs.

Table 7 shows that breaker specimen 17 always tripped at $27 \mathrm{~A}$ and $44^{\circ} \mathrm{F}$ ambient temperature. At $25 \mathrm{~A}$ the circuit breaker tripped during run $\equiv_{4}$ in about twenty minutes; however, in repeating run $\$ 4$ as run $\$ 5$, the breaker did not trip.

Results for the test of circuit breaker $\$$; are shown in table 8 . The circuit breaker had not tripped at the end of run $\$ 5$ at $25 \mathrm{~A}$ and $44^{\circ} \mathrm{F}$ and at that time the current was increased to $26 \mathrm{~A}$ without tripping the circuit breaker during an additional three-and one-half hours as run $\#^{6}$.

Table 9 gives results for the test of circuit breaker $\equiv^{9}$. The circuit breaker tripped at $26 \mathrm{~A}$ and $44^{\circ} \mathrm{F}$. The circuit breaker did not trip at $27 \mathrm{~A}$ and $32^{\circ} \mathrm{F}$.

\subsection{TEST RESULTS FOR FUSES}

Tables 10 and 11 show results for standard $20 \mathrm{~A}$ plug fuses. These were tested over the temperature range $30^{\circ} \mathrm{F}$ to $77^{\circ} \mathrm{F}$ and current range $22 \mathrm{~A}$ to $40 \mathrm{~A}$. At $22 \mathrm{~A}$ and $23 \mathrm{~A}$ and $44^{\circ} \mathrm{F}$, fuses did not blow. The $44^{\circ} \mathrm{F}$ ambient temperature data of table 10 shows that fuse currents had to be reduced to 22 or 23 A to prevent fuses from blowing. Comparison of the data in tables 10 and 11 shows that a reduction in the ambient temperature from $77^{\circ} \mathrm{F}$ to $31^{\circ} \mathrm{F}$ almost doubled the time for a fuse to open the circuit when carrying $27 \mathrm{~A}$.

Tables 7 and 8 show that circuit breakers would not trip when carrying $25 \mathrm{~A}$ when the ambient temperature was $44^{\circ} \mathrm{F}$. Fuses in table 10 show better performance than circuit breakers at this temperature. These fuses blew at 24 and $25 \mathrm{~A}$. 
TABLE 4. Test of Circuit Breaker \#2 at $25 \mathrm{~A}$ and $27 \mathrm{~A}$ Within the Temperature Range $39^{\circ} \mathrm{F}$ to $77^{\circ} \mathrm{F}$

\begin{tabular}{ccccc}
\hline Run & $\begin{array}{c}\text { Ambient } \\
\text { Temperature } \\
{ }^{\circ} \text { F }\end{array}$ & $\begin{array}{c}\text { Current } \\
\text { Amperes }\end{array}$ & Trip & $\begin{array}{c}\text { Run Time } \\
\text { Seconds }\end{array}$ \\
\hline 2 & 59 & 27 & Yes & 204.2 \\
3 & 54 & 27 & Yes & 239 \\
4 & 54 & 25 & Yes & 2280 \\
5 & 39 & 27 & Yes & 611 \\
6 & 39 & 25 & Yes & 3540 \\
7 & 77 & 25 & Yes & 410 \\
8 & 77 & 25 & Yes & 481 \\
9 & 77 & 25 & Yes & 285 \\
10 & 77 & 27 & Yes & 100 \\
11 & 77 & 27 & Yes & 231.4 \\
\hline 12 & 77 & 27 & Yes & 121.7 \\
\hline
\end{tabular}


TABLE 5. Test of Circuit Breaker \#3 over Current Range $24 \mathrm{~A}$ to $40 \mathrm{~A}$ and Temperature Range $49^{\circ} \mathrm{F}$ to $78^{\circ} \mathrm{F}$

\begin{tabular}{|c|c|c|c|c|c|}
\hline 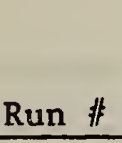 & $\begin{array}{l}\text { Ambient } \\
\text { Temperature } \\
\left({ }^{\circ} \mathrm{F}\right)\end{array}$ & $\begin{array}{c}\text { Current } \\
\text { (Amperes) }\end{array}$ & $\operatorname{Tr} 1 \mathrm{p}$ & $\begin{array}{r}\text { Run } \\
\text { (Seconds) } \\
\end{array}$ & $\begin{array}{l}\text { me } \\
\text { (Hours) }\end{array}$ \\
\hline 1 & 59 & 27 & Yes & 399.2 & \\
\hline 2 & 59 & 24 & No & & 4 \\
\hline 3 & 59 & 25 & Yes & 802 & \\
\hline 4 & 49 & 27 & No & & 2 \\
\hline 5 & 49 & 27 & Yes & 415 & \\
\hline 6 & 49 & 27 & Yes & 1009 & \\
\hline 7 & 49 & 25 & No & & 7 \\
\hline 8 & 77 & 25 & Yes & 1620 & \\
\hline 9 & 78 & 25 & No & & 2 \\
\hline 10 & 77 & 27 & Yes & 180 & \\
\hline 11 & 77 & 27 & Yes & 444 & \\
\hline 12 & 77 & 27 & Yes & 180 & \\
\hline 13 & 77 & 40 & Yes & 20 & \\
\hline 14 & 77 & 40 & Yes & 15 & \\
\hline 15 & 77 & 40 & Yes & 23 & \\
\hline 16 & 77 & 40 & Yes & 23 & \\
\hline 17 & 77 & 40 & Yes & 22 & \\
\hline
\end{tabular}


TABLE 6. Test of Circuit Breaker $\|_{4}$ over Current Range $27 \mathrm{~A}$ to $40 \mathrm{~A}$ and Temperature Range $44^{\circ} \mathrm{F}$ to $77^{\circ} \mathrm{F}$

\begin{tabular}{|c|c|c|c|c|c|c|}
\hline Run 非 & $\begin{array}{c}\text { Ambient } \\
\text { Temperature } \\
\left({ }^{\circ} \mathrm{F}\right)\end{array}$ & $\begin{array}{l}\text { Current } \\
\text { Amperes }\end{array}$ & Trip & $\begin{array}{c}\text { Run } \\
\text { (Seconds) }\end{array}$ & $\begin{array}{l}\text { me } \\
\text { (Hours) }\end{array}$ & $\begin{array}{c}\text { Temperature/ } \\
\text { Screw }\end{array}$ \\
\hline 1 & 77 & 27 & Yes & 950 & & \\
\hline 2 & 77 & 27 & Yes & 1403 & & \\
\hline 3 & 77 & 27 & Yes & 982 & & \\
\hline 4 & 77 & 40 & Yes & 28 & & \\
\hline 5 & 77 & 40 & Yes & 25 & & \\
\hline 6 & 77 & 40 & Yes & 28 & & \\
\hline 7 & 44 & 27 & No & & 3.7 & \\
\hline 8 & 45 & 28 & Yes & 591 & & 91 \\
\hline 9 & 45 & 27 & No & & 4 & 95 \\
\hline
\end{tabular}


TABLE 7. Test of Circuit Breaker $\# 7$ over Current Range $25 \mathrm{~A}$ to $40 \mathrm{~A}$ and Temperature Range $44^{\circ} \mathrm{F}$ to $77^{\circ} \mathrm{F}$

\begin{tabular}{|c|c|c|c|c|c|}
\hline Run 非 & $\begin{array}{c}\text { Ambient } \\
\text { Temperature } \\
\left({ }^{\circ} \mathrm{F}\right)\end{array}$ & $\begin{array}{c}\text { Current } \\
\text { (Amperes) }\end{array}$ & Trip & $\begin{array}{r}\text { Run } \\
\text { (Seconds) } \\
\end{array}$ & $\begin{array}{l}\text { Time } \\
\text { (Hours) }\end{array}$ \\
\hline 1 & 44 & 27 & Yes & 472 & \\
\hline 2 & 44 & 27 & Yes & 360 & \\
\hline 3 & 45 & 27 & Yes & 400 & \\
\hline 4 & 44 & 25 & Yes & 1307 & \\
\hline 5 & 44 & 25 & No & & 2.7 \\
\hline 6 & 77 & 27 & Yes & 210 & \\
\hline 7 & 77 & 27 & Yes & 211 & \\
\hline 8 & 77 & 27 & Yes & 234 & \\
\hline 9 & 77 & 27 & Yes & 240 & \\
\hline 10 & 77 & 40 & Yes & 30 & \\
\hline 11 & 77 & 40 & Yes & 24 & \\
\hline 12 & 77 & 40 & Yes & 32 & \\
\hline 13 & 77 & 40 & Yes & 33 & \\
\hline 14 & 77 & 40 & Yes & 31 & \\
\hline 15 & 77 & 40 & Yes & 31 & \\
\hline
\end{tabular}


TABLE 8. Test of Circuit Breaker $\$$. 8 over Current Range $25 \mathrm{~A}$ to $27 \mathrm{~A}$ and Temperature Range $32^{\circ} \mathrm{F}$ to $44^{\circ} \mathrm{F}$

\begin{tabular}{|c|c|c|c|c|c|}
\hline Run 非 & $\begin{array}{c}\text { Ambient } \\
\text { Temperature } \\
\left({ }^{\circ} \mathrm{F}\right)\end{array}$ & $\begin{array}{c}\text { Current } \\
\text { (Amperes) }\end{array}$ & Trip & $\begin{array}{c}\text { Run ? } \\
\text { (Seconds) } \\
\end{array}$ & $\begin{array}{l}\text { ime } \\
\text { (Hours) }\end{array}$ \\
\hline 1 & 43 & 27 & Yes & 561 & \\
\hline 2 & 44 & 27 & Yes & 515 & \\
\hline 3 & 44 & 27 & Yes & 619 & \\
\hline 4 & 44 & 25 & No & 2460 & \\
\hline 5 & 44 & 25 & No & & 4.3 \\
\hline 6 & 44 & 26 & No & & 3.5 \\
\hline 7 & 32 & 27 & Yes & 672 & \\
\hline 8 & 32 & 27 & Yes & 556 & \\
\hline 9 & 32 & 27 & Yes & 610 & \\
\hline 10 & 32 & 26 & Yes & & 1.1 \\
\hline
\end{tabular}


TABLE 9. Test of Circuit Breaker $\$$ 师 over Current Range $26 \mathrm{~A}$ to $40 \mathrm{~A}$ and Temperature Range $32^{\circ} \mathrm{F}$ to $77^{\circ} \mathrm{F}$

\begin{tabular}{|c|c|c|c|c|c|}
\hline Run 非 & $\begin{array}{l}\text { Ambient } \\
\text { Temperature } \\
\left({ }^{\circ} \mathrm{F}\right)\end{array}$ & $\begin{array}{l}\text { Current } \\
\text { Amperes }\end{array}$ & Trip & $\begin{array}{l}\text { Run } \\
\text { (Seconds) }\end{array}$ & $\begin{array}{l}\text { Time } \\
\text { (Hours) }\end{array}$ \\
\hline 1 & 44 & 26 & Yes & 1179 & \\
\hline 2 & 44 & 26 & Yes & 3517 & \\
\hline 3 & 32 & 27 & No & & 6.5 \\
\hline 4 & 77 & 27 & Yes & 288 & \\
\hline 5 & 77 & 27 & Yes & 307 & \\
\hline 6 & 77 & 27 & Yes & 297 & \\
\hline 7 & 77 & 40 & Yes & 37 & \\
\hline 8 & 77 & 40 & Yes & 36 & \\
\hline 9 & 77 & 40 & Yes & 37 & \\
\hline
\end{tabular}


TABLE 10. Test of Standard 20 A Plug Fuses over Current Range $23 \mathrm{~A}$ to $27 \mathrm{~A}$ and Temperature Range $31^{\circ} \mathrm{F}$ to $44^{\circ} \mathrm{F}$

\begin{tabular}{|c|c|c|c|c|c|}
\hline Fuse 非 & $\begin{array}{c}\begin{array}{c}\text { Ambient } \\
\text { Temperature } \\
\left({ }^{\circ} \mathrm{F}\right)\end{array} \\
\end{array}$ & $\begin{array}{c}\text { Current } \\
\text { (Amperes) }\end{array}$ & $\begin{array}{l}\text { Opened } \\
\text { Circuit } \\
\end{array}$ & $\begin{array}{r}\text { Run } \\
\text { (Seconds) } \\
\end{array}$ & $\begin{array}{l}\text { ime } \\
\text { (Hours) }\end{array}$ \\
\hline 1 & 43 & 26 & Yes & 146 & \\
\hline 2 & 43 & 25 & Yes & 338 & \\
\hline 3 & 43 & 24 & Yes & 1708 & \\
\hline 4 & 44 & 24 & Yes & 765 & \\
\hline 5 & 44 & 23 & No & & 2.5 \\
\hline 6 & 44 & 23 & Yes & 554 & \\
\hline 7 & 44 & 22 & No & & 5.3 \\
\hline 8 & 44 & 26 & Yes & 167 & \\
\hline 9 & 44 & 25 & Yes & 332 & \\
\hline 10 & 44 & 24 & Yes & 1530 & \\
\hline 11 & 44 & 23 & No & & 1.4 \\
\hline 12 & 44 & 23 & No & & 4.2 \\
\hline 13 & 31 & 27 & Yes & 93 & \\
\hline 14 & 31 & 27 & Yes & 84 & \\
\hline 15 & 31 & 27 & Yes & 77 & \\
\hline 16 & 33 & 27 & Yes & 83 & \\
\hline
\end{tabular}


TABLE 11. Test of Standard 20 A Plug Fuses over Current Range 26 A to 40 A at Room Temperature

\begin{tabular}{|c|c|c|c|c|}
\hline Fuse 非 & $\begin{array}{c}\text { Ambient } \\
\text { Temperature } \\
\left({ }^{\circ} \mathrm{F}\right)\end{array}$ & $\begin{array}{c}\text { Current } \\
\text { (Amperes) }\end{array}$ & $\begin{array}{l}\text { Opened } \\
\text { Circuit } \\
\end{array}$ & $\begin{array}{l}\text { Run Time } \\
\text { Seconds }\end{array}$ \\
\hline 17 & 71 & 26 & Yes & 52 \\
\hline 18 & 77 & 26 & Yes & 94 \\
\hline 19 & 77 & 26 & Yes & 89 \\
\hline 20 & 77 & 26 & Yes & 90 \\
\hline 21 & ty & 26 & Yes & 73 \\
\hline 22 & 77 & 27 & Yes & 38 \\
\hline 23 & 77 & 27 & Yes & 54 \\
\hline 24 & 77 & 27 & Yes & 48 \\
\hline 25 & 77 & 27 & Yes & 43 \\
\hline 26 & 77 & 27 & Yes & 44 \\
\hline 27 & 77 & 40 & Yes & 2 \\
\hline 28 & 77 & 40 & Yes & 2.6 \\
\hline 29 & 77 & 40 & Yes & 2.7 \\
\hline 30 & 77 & 40 & Yes & 2.6 \\
\hline
\end{tabular}




\subsection{MULTI-CIRCUIT BREAKER TEST RESULTS}

Tables $12 \mathrm{~A}, 12 \mathrm{~B}$ and $12 \mathrm{C}$ show results for circuit breaker specimen \#1 tested at $27 \mathrm{~A}$ and $49^{\circ} \mathrm{F}$ ambient air temperature in the same load center with circuit breaker specimens 5 and 16 . Specimens 5 and 1 were in series and carried currents of $0,5,10,15$, and $19 \mathrm{~A}$. As shown in the tables, circuit breaker \#1 did not trip when operated four hours and fifteen minutes with circuit breakers 5 and $\$$ 非 6 not carrying current. Circuit breaker 11 did not trip when the circuit breakers 5 and 非 6 were operating at 15 A or less. However, circuit breaker 非 tripped consistently when circuit breakers $\$$ 涪 5 and 6 were operated at $19 \mathrm{~A}$. The heat generated by circuit breakers 5 and 6 resulted in a sufficient temperature rise in circuit breaker 11 to cause circuit breaker \#1 to trip. The temperature rise at circuit breaker 1 was $35^{\circ} \mathrm{F}$ when the current in circuit breakers 5 and 6 was increased by 4 amperes. (See run \#5 in table 12B and run 1 1 in table 12C). The total power generated in the circuit breakers with 15 A during run $\equiv^{5}$ of table $12 \mathrm{~B}$ was $20 \mathrm{Btu}$ per hour (6 watts) and with 19 A during run 1 l 1 of table $12 \mathrm{C}$ was 25.6 Btu per hour ( 7.5 watts). These heat rates were determined from the voltage drop across the circuit breakers and the currents given in the tables. 
Table 12A. Test of Breaker 1 Installed in an Enclosure with Breakers $\equiv^{5}$ \& $\# 6$ at $49^{\circ} \mathrm{F}$ Ambient Temperature

\begin{tabular}{|c|c|c|c|c|c|c|c|}
\hline Run & $\begin{array}{l}\text { Run Time } \\
\text { (Minutes) }\end{array}$ & $\begin{array}{l}\text { Breaker } \\
\text { Number }\end{array}$ & $\begin{array}{l}\text { Voltage } \\
\text { Drop- } \\
(\mathrm{mV})\end{array}$ & $\begin{array}{l}\text { Current- } \\
\text { (A) }\end{array}$ & $\begin{array}{l}\text { Breaker 非1 } \\
\text { Trip Time - } \\
\text { (Minutes) }\end{array}$ & Screw & $\begin{array}{l}\text { Temperature } \\
\left({ }^{\circ} \mathrm{F}\right)\end{array}$ \\
\hline 1 & $\begin{array}{r}252 \\
-- \\
--\end{array}$ & $\begin{array}{l}1 \\
5 \\
6\end{array}$ & $\begin{array}{c}146.3 \\
0 \\
0\end{array}$ & $\begin{array}{c}27.19 \\
0 \\
0\end{array}$ & $\begin{array}{c}\text { Did not } \operatorname{Trip} \\
- \\
-\end{array}$ & & $\begin{array}{l}87 \\
-- \\
--\end{array}$ \\
\hline 2 & $\begin{array}{l}256 \\
\ddot{~}\end{array}$ & $\begin{array}{l}1 \\
5 \\
6\end{array}$ & $\begin{array}{r}146.0 \\
23.5 \\
23.0\end{array}$ & $\begin{array}{r}27.07 \\
4.93 \\
4.93\end{array}$ & $\begin{array}{c}\text { Did not Trip } \\
- \\
-\end{array}$ & & $\begin{array}{l}85 \\
-- \\
--\end{array}$ \\
\hline & $\begin{array}{c}335 \\
. "\end{array}$ & $\begin{array}{l}1 \\
5 \\
6\end{array}$ & $\begin{array}{r}145.3 \\
23.0 \\
24.0\end{array}$ & $\begin{array}{r}27.00 \\
5.06 \\
5.06\end{array}$ & $\begin{array}{cc}\text { Did not } & \operatorname{Tr} i p \\
-- & \\
- & \end{array}$ & & $\begin{array}{l}87 \\
-- \\
--\end{array}$ \\
\hline 3 & $\begin{array}{l}337 \\
"\end{array}$ & $\begin{array}{l}1 \\
5 \\
6\end{array}$ & $\begin{array}{r}145.0 \\
47.9 \\
47.5\end{array}$ & $\begin{array}{l}26.98 \\
10.04 \\
10.04\end{array}$ & $\begin{array}{cc}\text { Did not Trip } \\
-- \\
--\end{array}$ & & $\begin{array}{l}87 \\
-- \\
--\end{array}$ \\
\hline & $\begin{array}{c}389 \\
"\end{array}$ & $\begin{array}{l}1 \\
5 \\
6\end{array}$ & $\begin{array}{r}146.1 \\
48.0 \\
47.7\end{array}$ & $\begin{array}{r}27.11 \\
9.97 \\
9.97\end{array}$ & $\begin{array}{cc}\text { Did not } & \text { Trip } \\
-- & \\
-- & \end{array}$ & & $\begin{array}{l}88 \\
-- \\
--\end{array}$ \\
\hline
\end{tabular}


Table 12B. Test of Breaker \#1 Installed in an Enclosure with Breakers \#5\& \#6 at $49^{\circ} \mathrm{F}$ Ambient Temperature

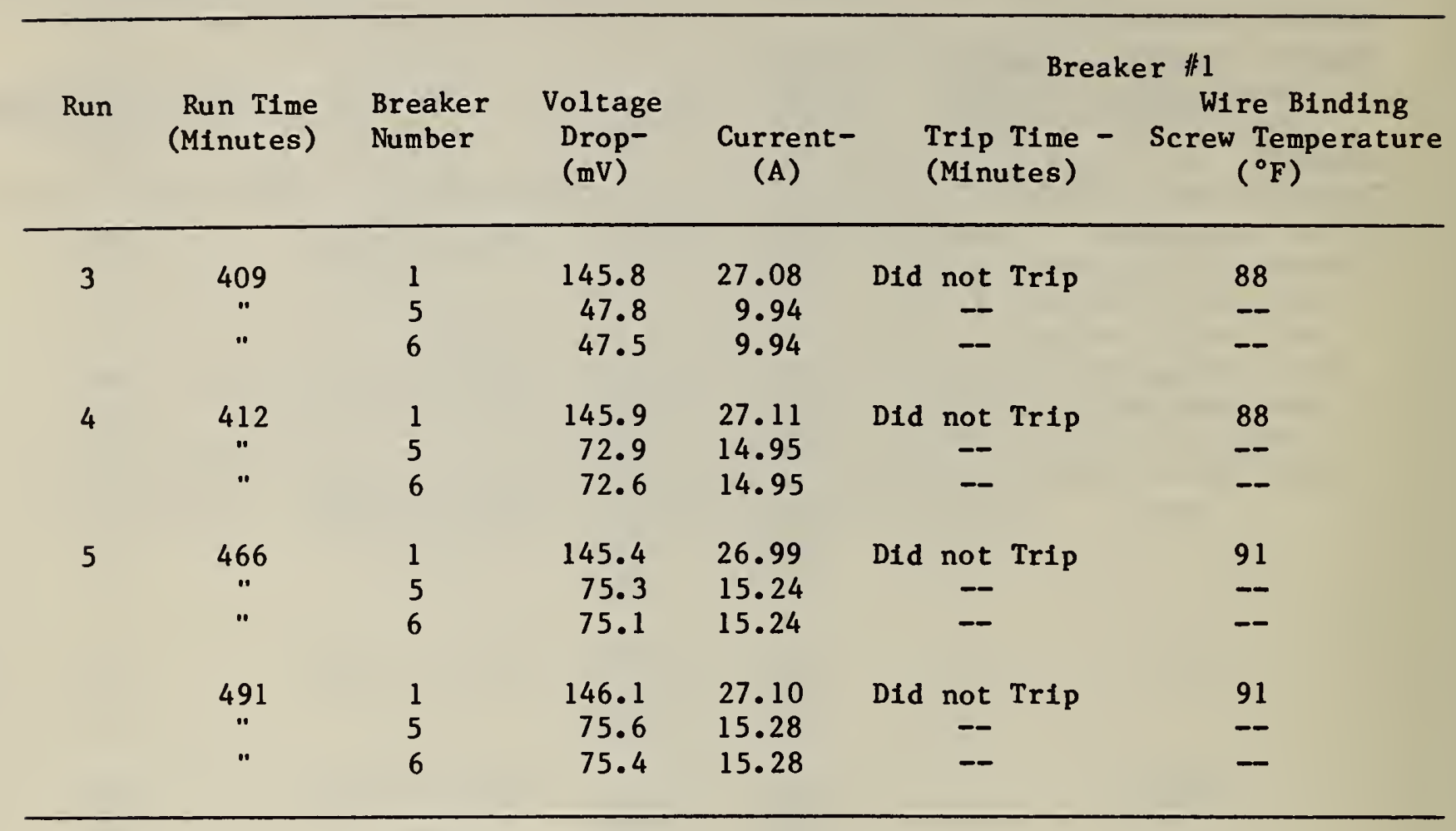


Table 12C. Test of Breaker \#1 Installed in an Enclosure with Breakers $\# 5$ \& $\# 6$ at $49^{\circ} \mathrm{F}$ Ambient Temperature

\begin{tabular}{|c|c|c|c|c|c|c|}
\hline Run & $\begin{array}{l}\text { Run Time } \\
\text { (Minutes) }\end{array}$ & $\begin{array}{l}\text { Breaker } \\
\text { Number }\end{array}$ & $\begin{array}{l}\text { Vol tage } \\
\text { Drop- } \\
(\mathrm{mV})\end{array}$ & $\begin{array}{l}\text { Current- } \\
\text { (A) }\end{array}$ & $\begin{array}{l}\text { Break } \\
\text { Trip Time - } \\
\text { (Minutes) }\end{array}$ & 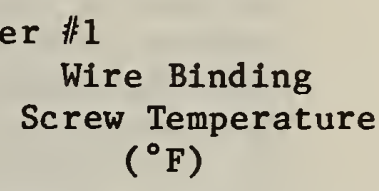 \\
\hline 1 & 30 & $\begin{array}{l}1 \\
5 \\
6\end{array}$ & $\begin{array}{r}139.8 \\
96.7 \\
97.1\end{array}$ & $\begin{array}{l}27.10 \\
19.05 \\
19.05\end{array}$ & $\begin{array}{r}30 \\
* \\
*\end{array}$ & -- \\
\hline 2 & 6.7 & $\begin{array}{l}1 \\
5 \\
6\end{array}$ & $\begin{array}{r}145.7 \\
95.2 \\
96.1\end{array}$ & $\begin{array}{l}27.77 \\
19.10 \\
19.10\end{array}$ & $\begin{array}{l}6.7 \\
\star \\
*\end{array}$ & $\begin{array}{l}-- \\
-- \\
--\end{array}$ \\
\hline 3 & 16.7 & $\begin{array}{l}1 \\
5 \\
6\end{array}$ & $\begin{array}{r}147.1 \\
95.4 \\
96.3\end{array}$ & $\begin{array}{l}27.29 \\
19.06 \\
19.06\end{array}$ & $\begin{array}{c}16.7 \\
\star \\
\star\end{array}$ & $\begin{array}{l}-- \\
-- \\
--\end{array}$ \\
\hline
\end{tabular}

* Breakers $\$$ 5 and $\# 6$ did not trip 


\section{CIRCUIT BREAKER PERFORMANCE UNDER SHORT CIRCUIT CONDITIONS}

The NEMA standard for molded-case circuit breakers presents data concerning the maximum available short circuit current in service drops* [4]. The data indicate a potential for several thousand amperes of short-circuit current between line and ground. Actual short-circuit current in a particular residence is governed by transformer characteristics, length and wire size, and resistance of the service drop. Examples of NEMA data are given in table 13. The table gives currents in a service drop which was shorted at various distances from distribution transformers [4]. Similar currents could occur in short circuits within service entrance equipment. Therefore, a circuit breaker must be designed to interrupt large short-circuit currents without damage to itself or other elements of the building system. Circuit breakers used in these investigations were rated to interrupt $10,000 \mathrm{~A}$.

The American Electricians' Handbook indicates that there is no easy calculation or accurate predictive approach available for determining short-circuit currents at various points in a given installation [7]. There are unknown factors that must be determined before accurate calculations can be made [7]. One such unknown is circuit impedance.

Within a residence, large short-circuit currents could occur in branch circuits at locations close to the load center. Because of branch circuit conductor resistance, short-circuit currents are smaller at locations farther from the load center. The short-circuit current, line to ground, at the end of the branch circuit in figure 4 would be about 490 A (calculated from $0 \mathrm{hm}^{\prime} \mathrm{s}$ law.) of course, short circuits at other positions in the branch could have higher currents. Certain motors or capacitors operating during the time of the short circuit would add some current to the fault and increase the shortcircuit current. Based on the above calculations, the magnitudes of shortcircuit currents generated under laboratory conditions as presented in this section were chosen as representative for general purpose residential branch circuits.

\subsection{SHORT-CIRCUIT TEST SETUP AND TEST PROCEDURE}

The laboratory experiments presented in this section were conducted to determine if short circuits caused by nail penetration would be cleared by overcurrent protection devices before ignition of combustibles could occur.

The short-circuit tests used the assembly shown in figure 5 to create the short-circuit. This figure represents the nominal 2" $x$ 4" wooden wall stud. The nall shown in figure 5 was driven through the stud into the cable. The

* Service drop: the overhead service conductors from the last pole or other aerial support to and including the splices, if any, connecting to the service-entrance conductors at the building or other structure [1]. See the service drop in figure 4 . 
Table 13. Symmetrical Single-Phase Short-Circuit Current in Amperes with 120 Volts Line to Ground at Various Distances in 非 AWG 3-Wire Cable from Various Residential Type Distribution Transformers Rated $120 / 240$ Volts

\begin{tabular}{|c|c|c|c|}
\hline \multirow{2}{*}{$\begin{array}{l}\text { Distance From } \\
\text { Transformer } \\
\text { (Feet) }\end{array}$} & \multicolumn{3}{|c|}{$\begin{array}{c}\text { Short-Circuit Current, Amperes } \\
\text { Transformer Size }\end{array}$} \\
\hline & $25 \mathrm{kVA}$ & $37.5 \mathrm{kVA}$ & $100 \mathrm{kVA}$ \\
\hline 0 & 8780 & 13830 & 35187 \\
\hline 5 & 6927 & 10904 & 20845 \\
\hline 10 & 6023 & 8843 & 14156 \\
\hline 25 & 4268 & 5497 & 7031 \\
\hline 50 & 2835 & 3318 & 3792 \\
\hline 75 & 2114 & 2367 & 2593 \\
\hline 100 & 1683 & 1838 & 1969 \\
\hline
\end{tabular}




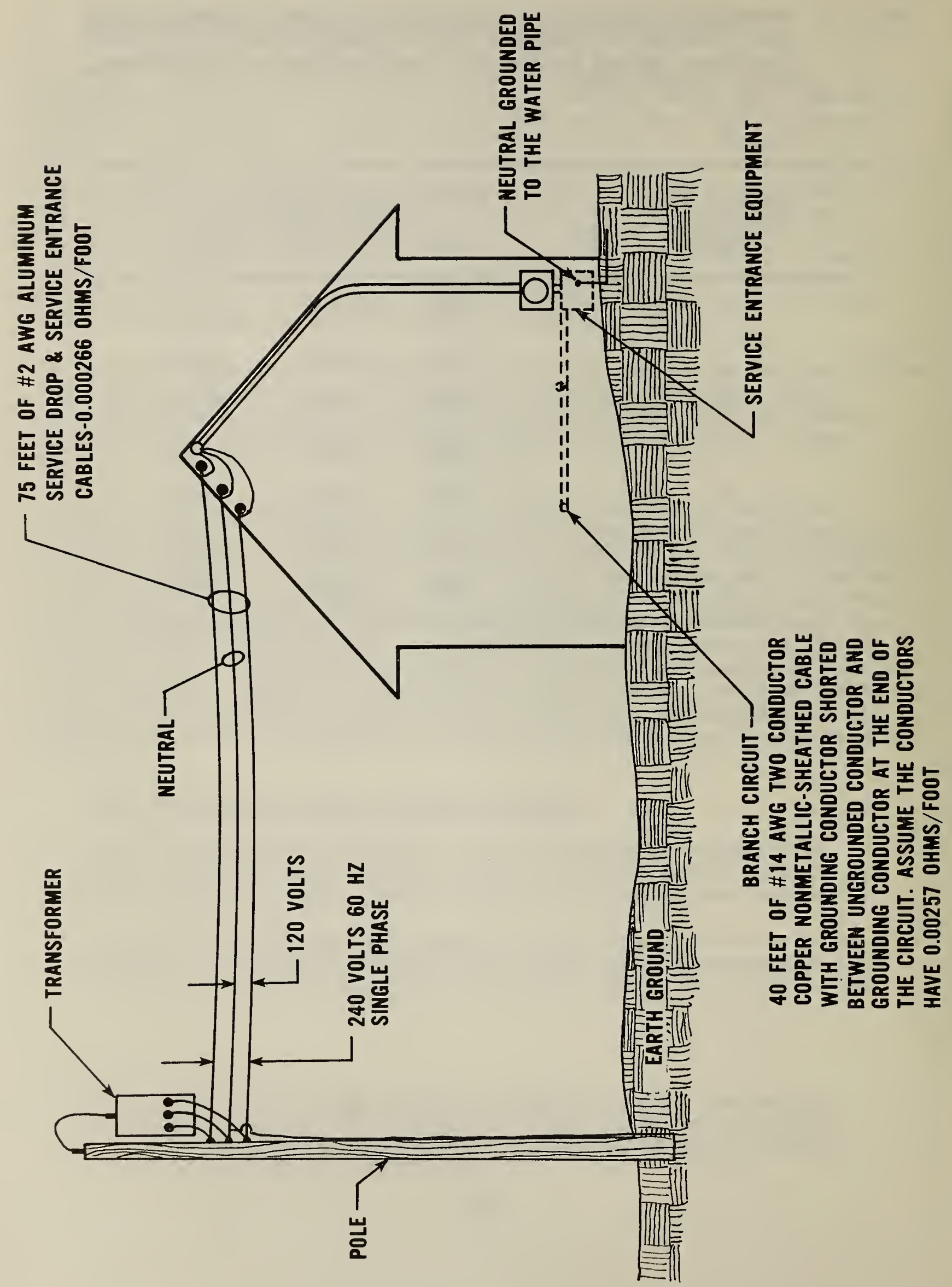




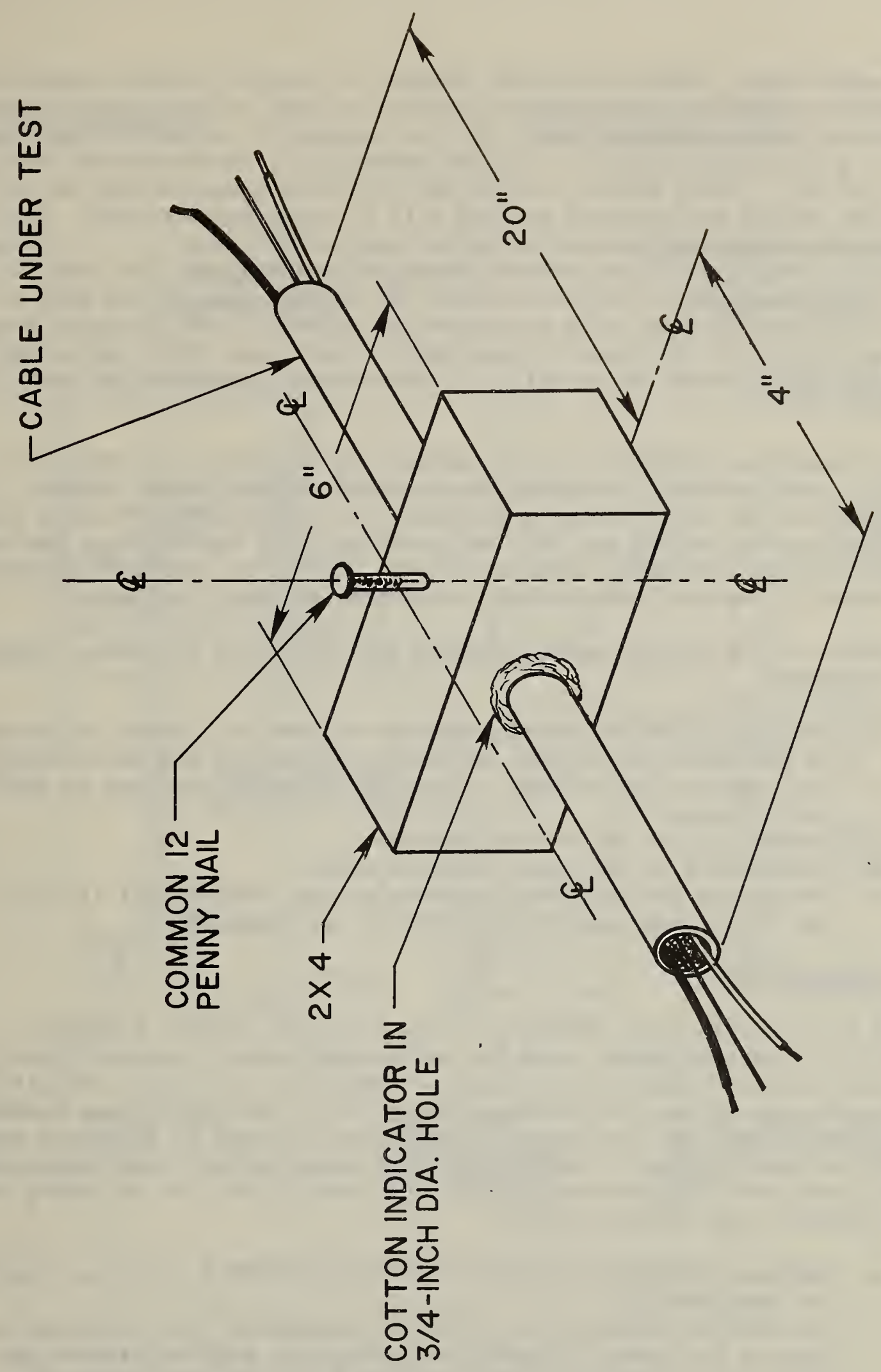

Figure 5. Short circuit specimen 
nail made contact (short-circuited) between a current-carrying conductor and grounding conductor. The cotton indicator was used to demonstrate possible ignition of nearby combustibles. The stud appears to be particularly vulnerable to penetration by nails. This vulnerability is considered by article 300-4 (a) (1), "Bored Holes," of the NEC [1] which requires that holes in studs for cables be protected against nail or screw penetrations. That portion of the article concerning studs reads as follows: ". . . holes in studs for cable-type wiring methods shall be bored so that the edge of the hole is not less than 1-1/4 inches from the nearest edge of the stud or shall be protected from nails and screws by either a steel plate or bushing at least $1 / 16$-inch thick and of appropriate length and width installed to cover the area through which nails or screws might penetrate the installed cable."

After installing the short-circuit specimen in the test setup shown in figure 6 , the specimen resistance was measured using a kelvin bridge. The resistance of the short could be determined by subtracting the known resistance of specimen wiring and test setup wiring. The initial test specimen temperature was recorded. Surgical cotton, used as an ignition indicator, was packed in the stud hole around the wiring, as shown in figure 5 .

Activation of the control switch powered the short; the following information was obtained:

a. Whether or not the circuit breaker tripped and number of cycles of current to trip (time of trip), recorded on the oscilloscope

b. Peak current and voltage - also line voltage, recorded on the oscilloscope.

c. Whether or not cotton was ignited.

d. Temperature on the cable near the short.

e. Whether or not the circuit opened at the shorted nail (if not, the final resistance of the circuit was measured).

\subsection{TEST RESULTS}

Tables 14A-14H (see pages 30-37) show short circuit results for both nonmetallic-sheathed cable, type NM, and armored cable, type AC. Results show the circuit breaker did not operate during 27 of 64 short-circuit tests. During those tests when the breaker did not trip, the circuit was opened at the conductor and nail interface by "explosive" melting of interface material during the short circuit. Temperature rise above ambient room temperature on the cable near the penetrating nail was about $20^{\circ} \mathrm{F}$. The following were also observed from tables $14 \mathrm{~A}-14 \mathrm{H}$ :

a. Maximum peak short-circuit currents were $1000 \mathrm{~A}$, the test results in (specimen \#2).

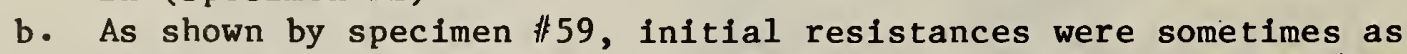
high as 4.27 ohms. Usually the relatively high resistance was unstable. Resistance variations of $+0.5 \mathrm{ohm}$ were observed.

c. The cotton indicators ignited ten times, and in one case the wooden stud was also ignited. 


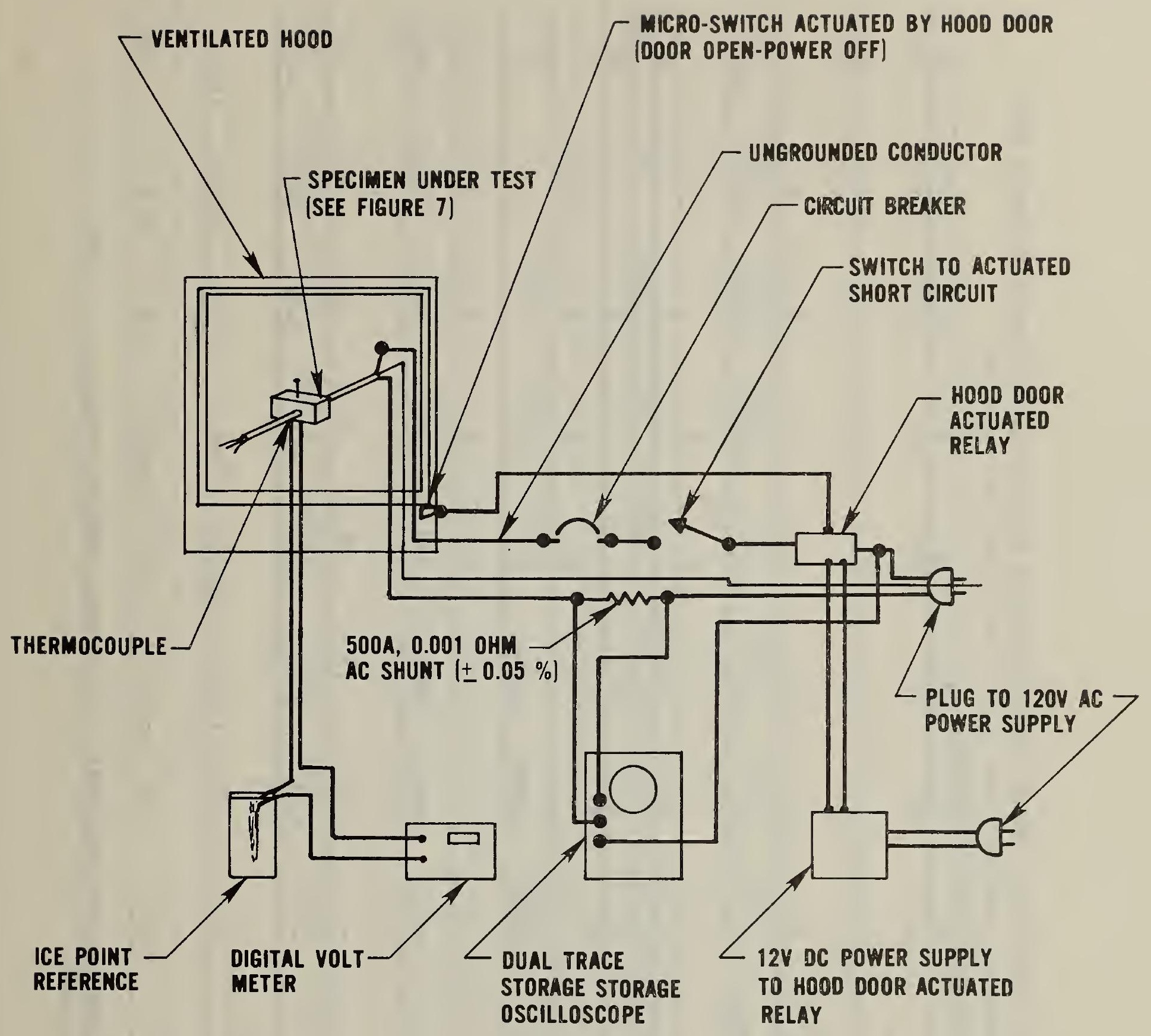

Figure 6. Short circuit test setup 


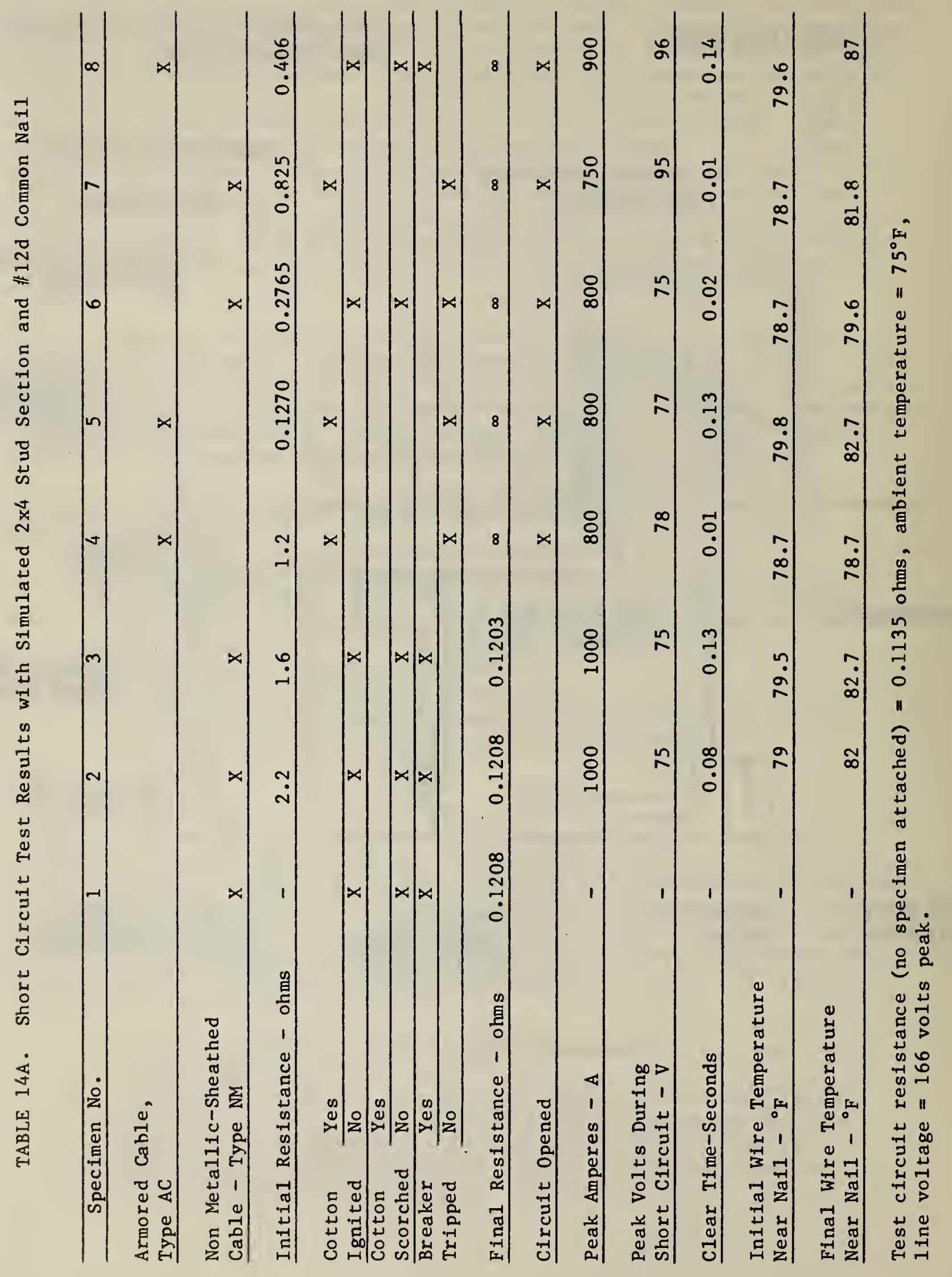




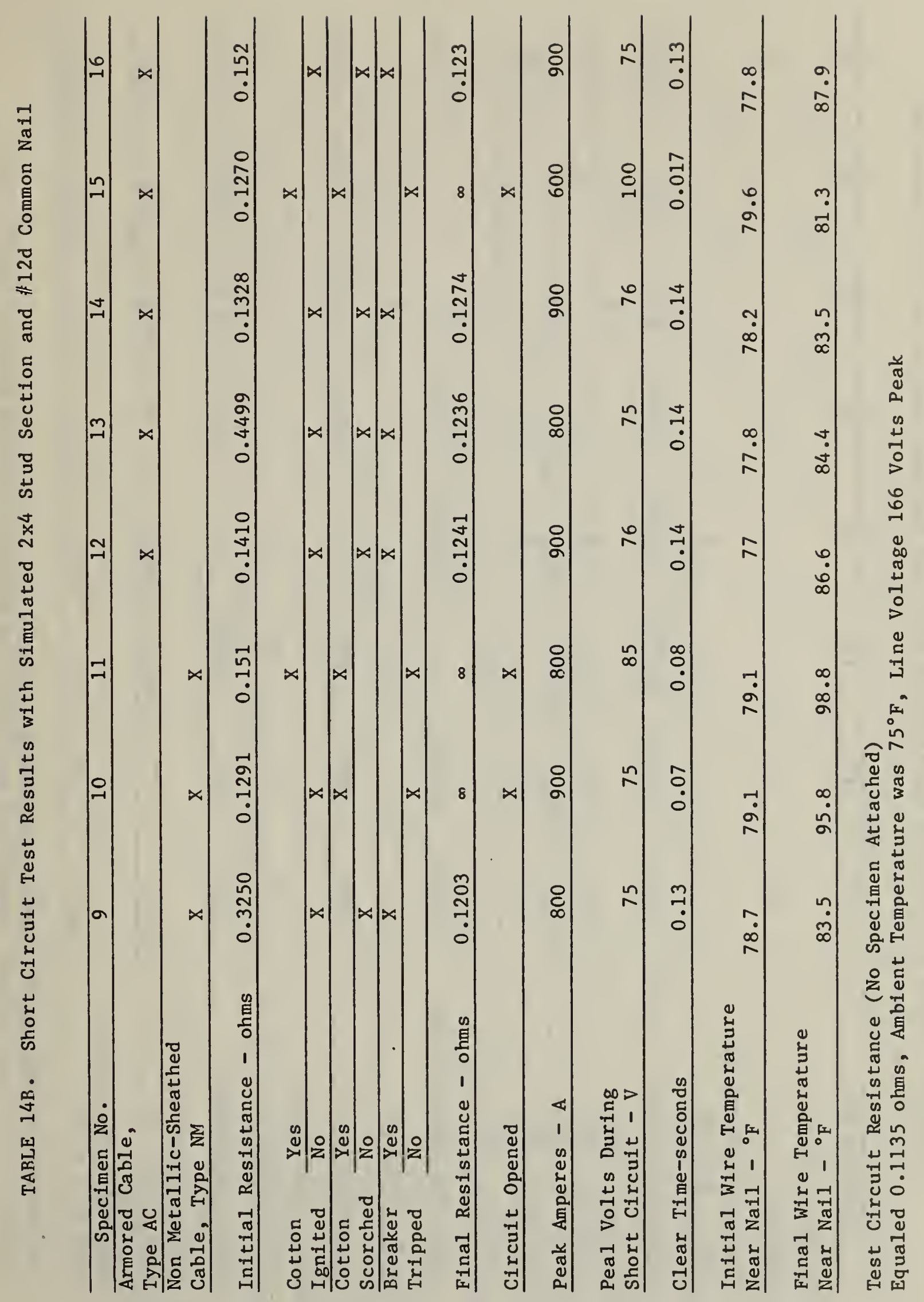




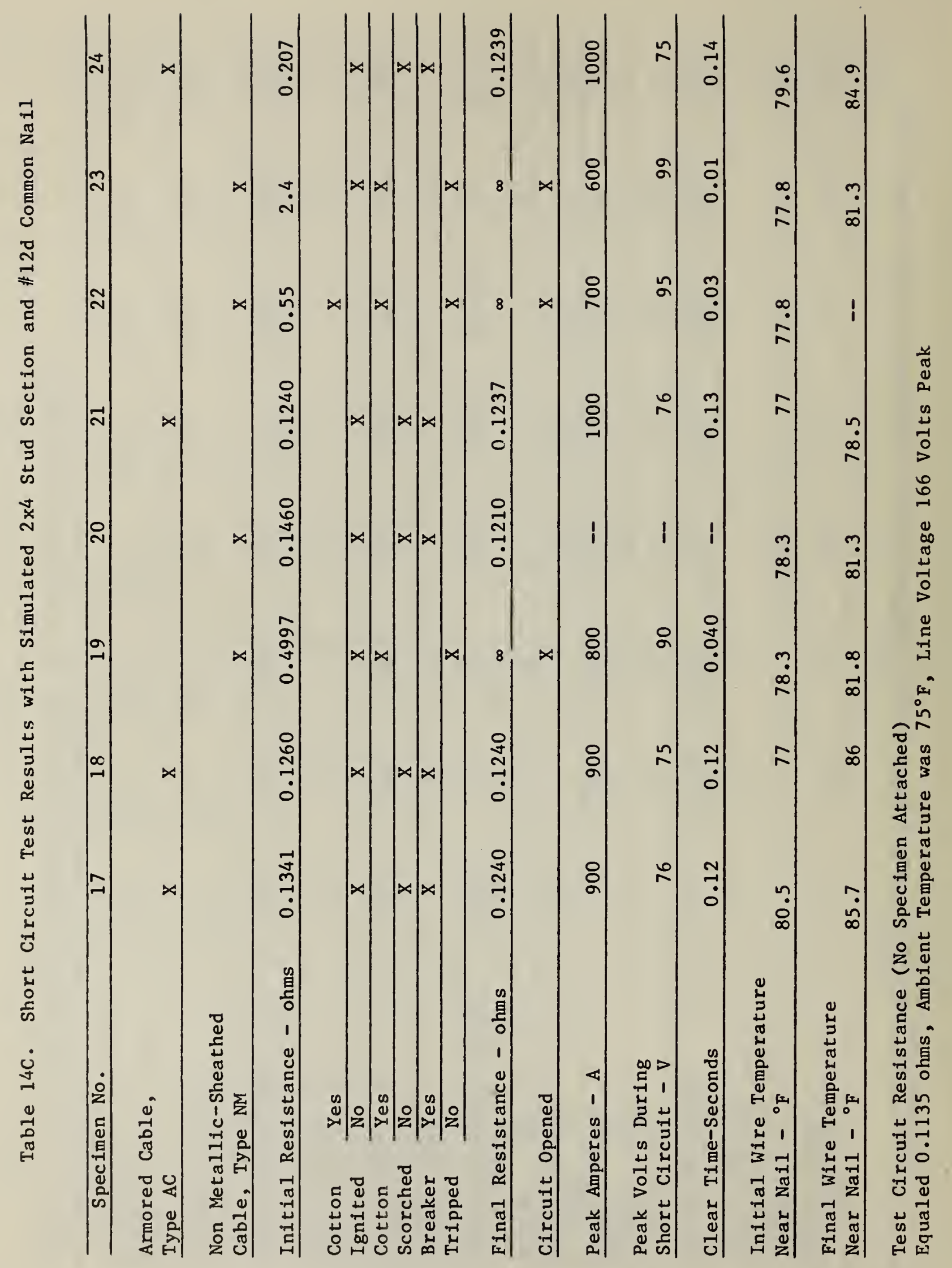




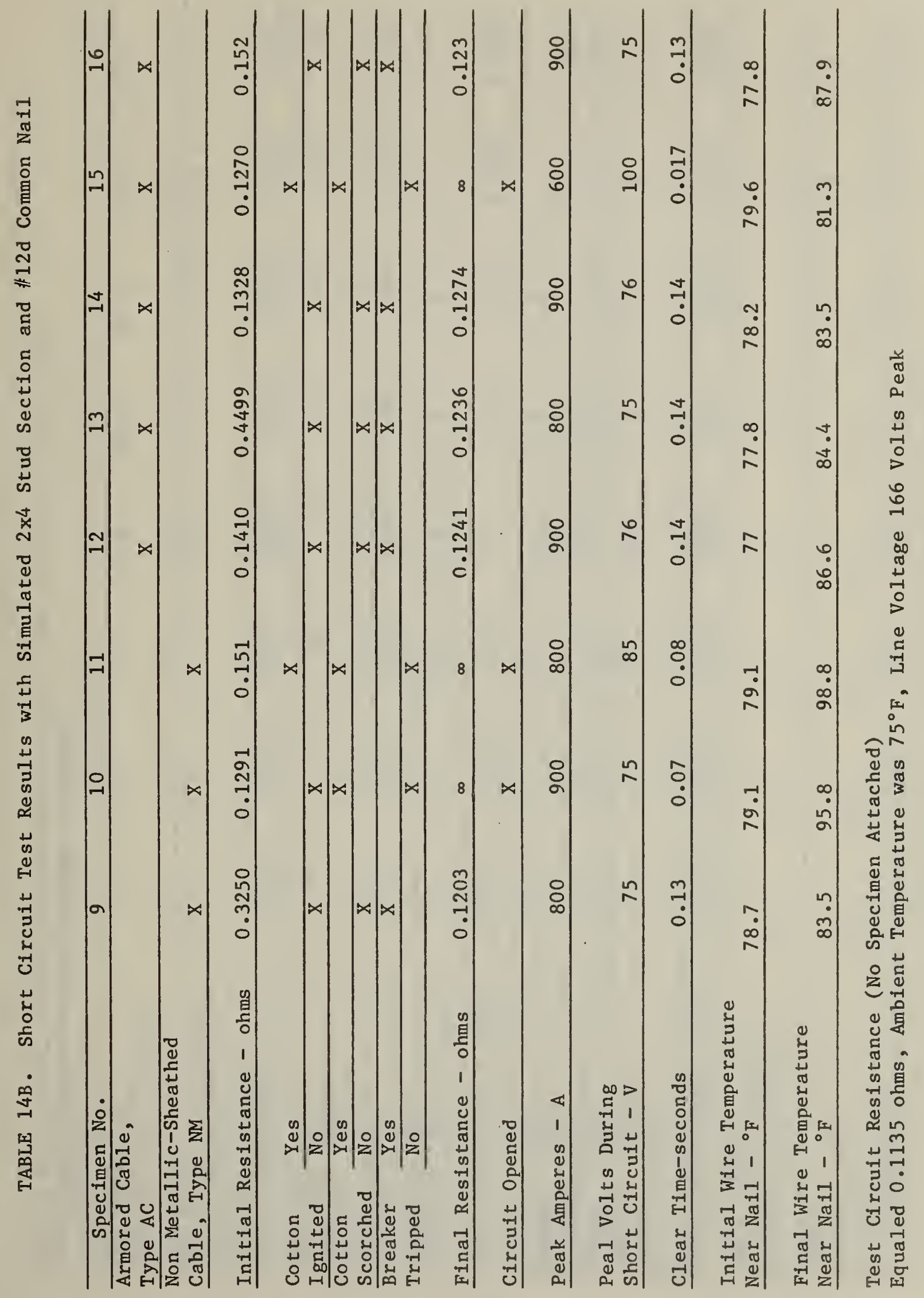




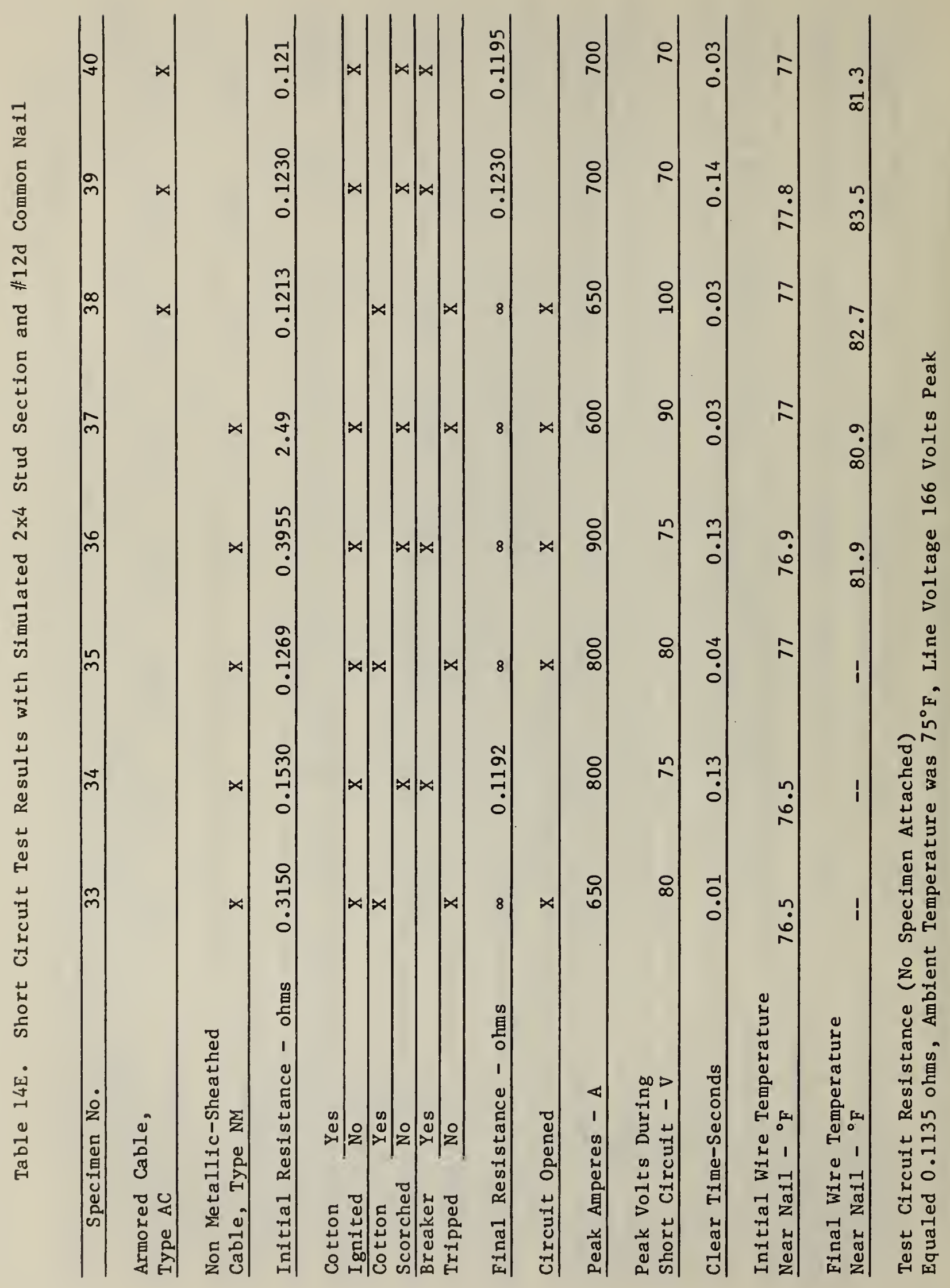




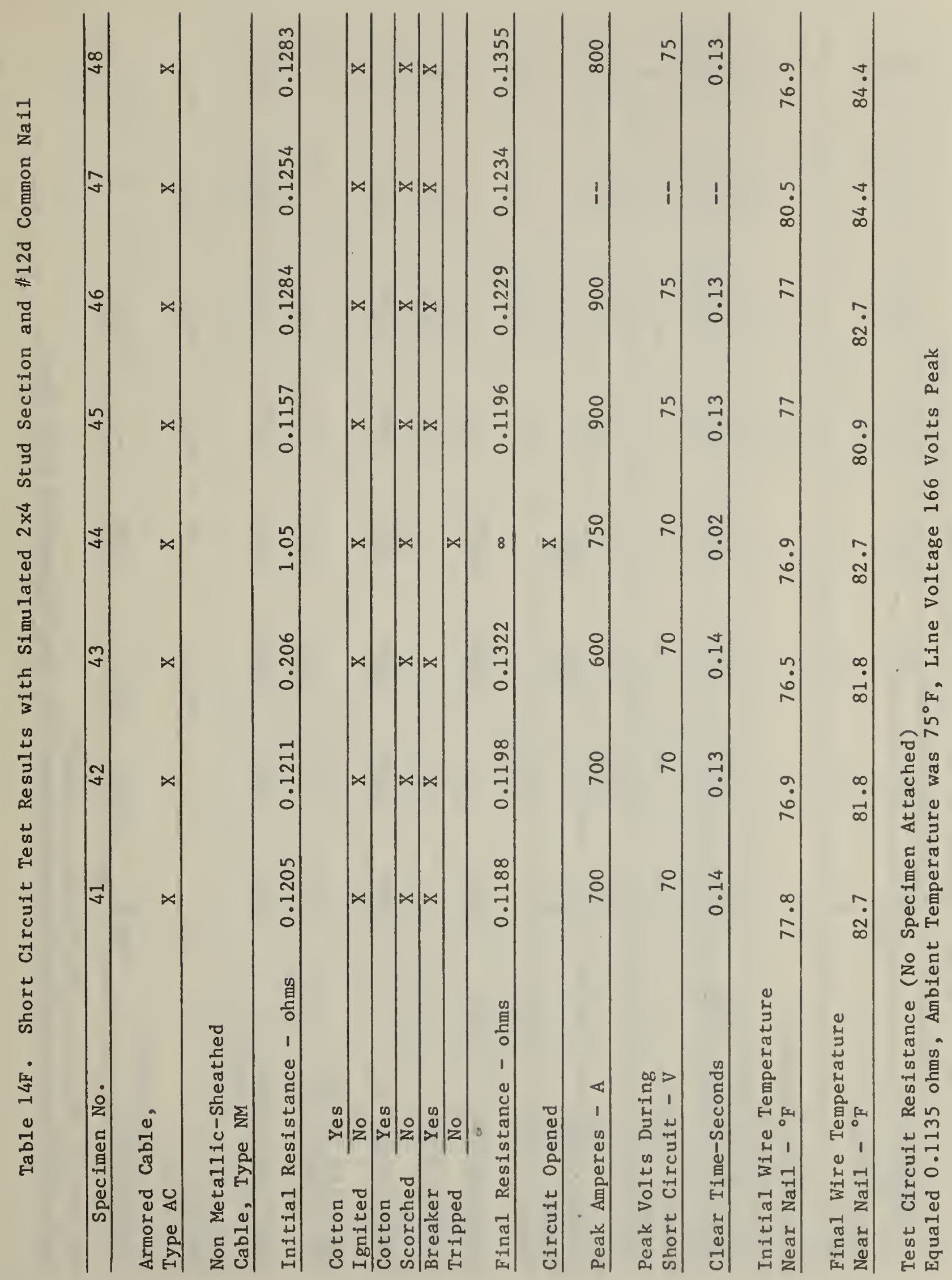




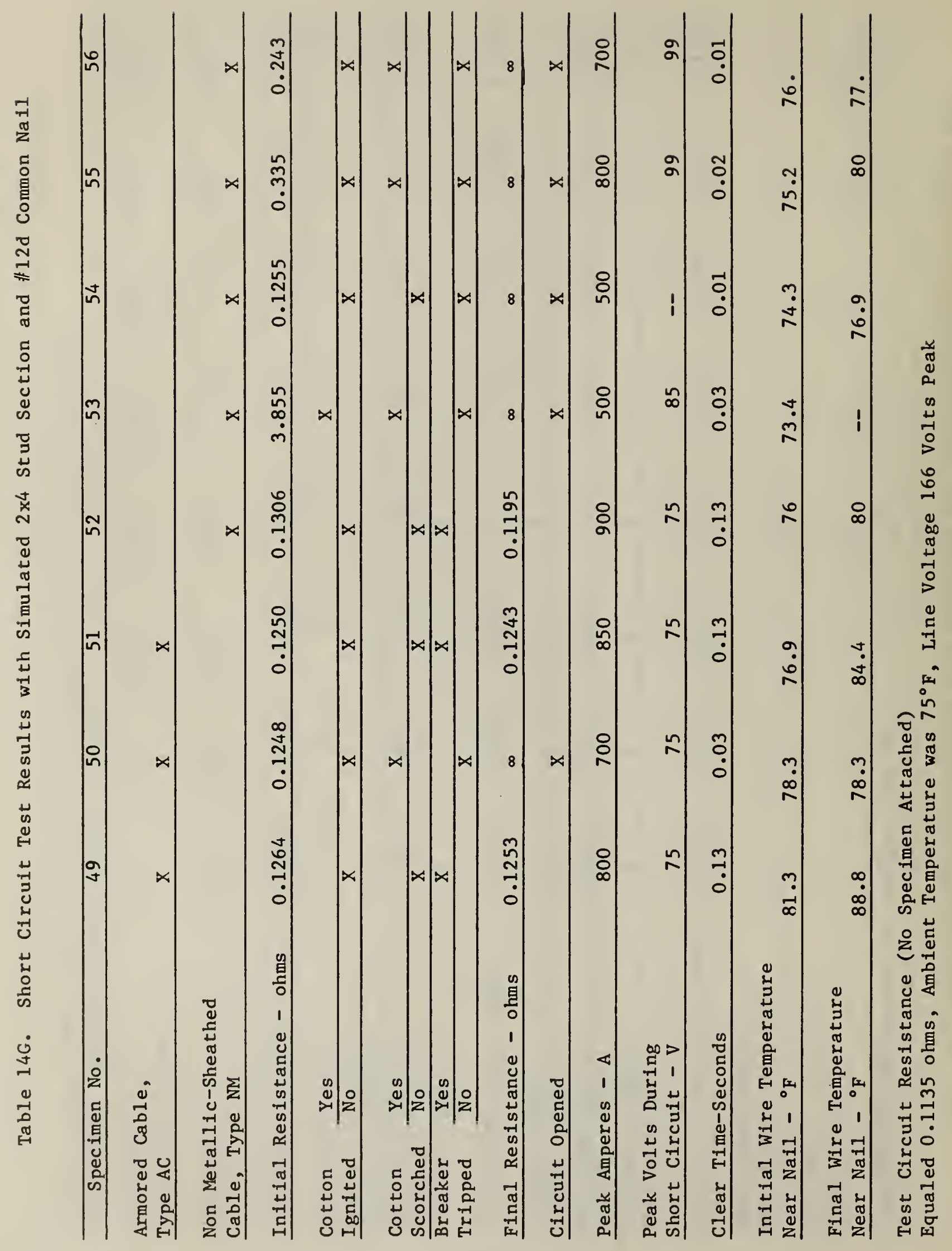




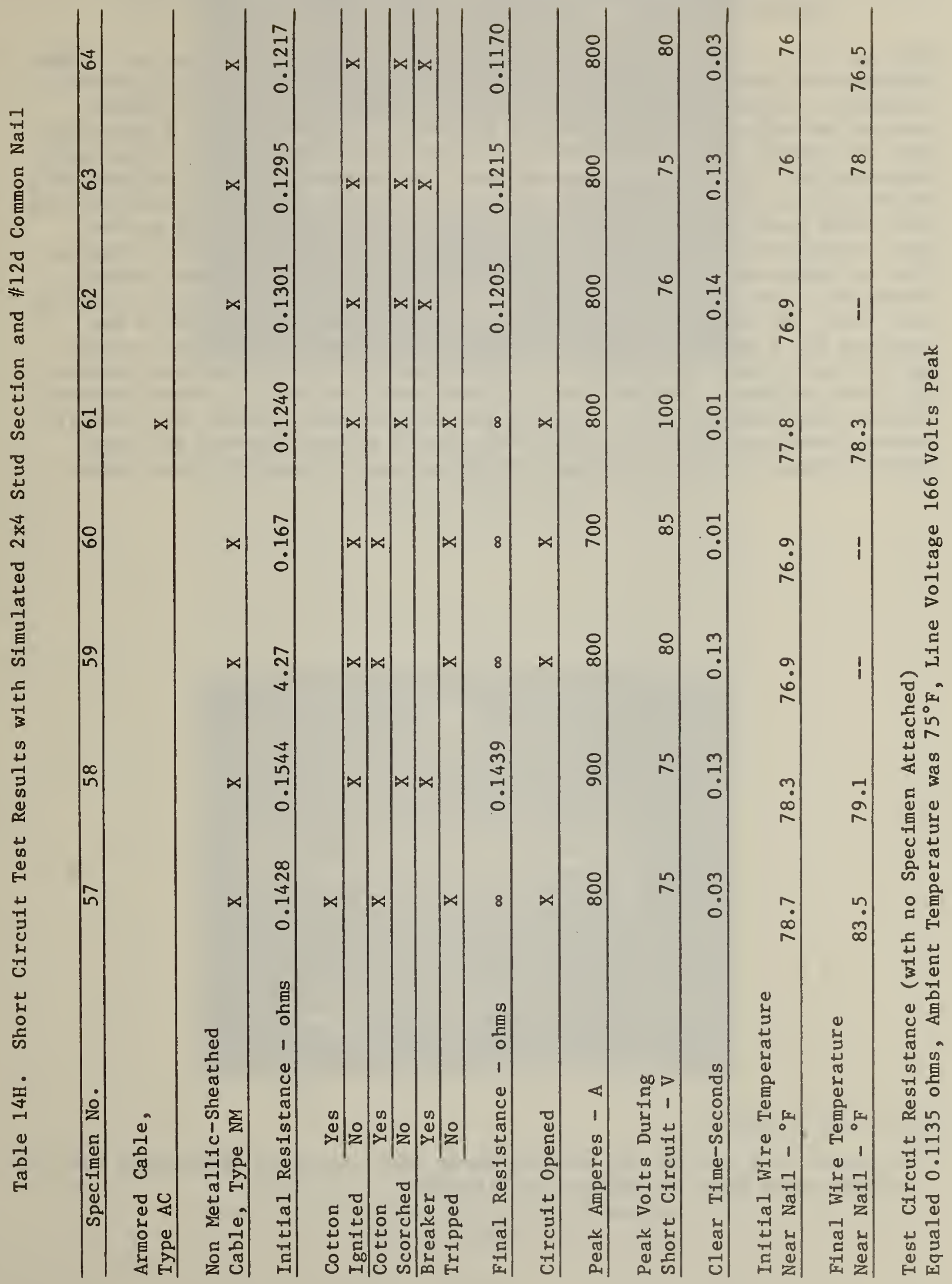


d. The cotton indicators were scorched 12 times without cotton ignition.

Figures 7,8,9 show oscilloscope records of selected short circuits. These figures show current and voltage drop in phase indicating, for all practical purposes, a purely resistive short circuit. Figure 7 shows no apparent current and voltage wave distortion. However, in figures 8 and 9 (for cases when the circuit breaker did not trip) both current and voltage waves were. distorted due to sporadic interruption of the current. This may be due to a thermostatting effect that makes and breaks contact between the nail and the wire, thus opening and closing the circuit. Opening and closing on the short circuit in this manner may prevent the circuit breaker from tripping. This is demonstrated by data in figure 9. As shown, the average current during the first cycle was $530 \mathrm{~A} \mathrm{rms}^{*}$. No current pulse occurred during the next $6 \mathrm{~ms}$. At the end of the $6 \mathrm{~ms}$ period, a current pulse of $350 \mathrm{~A} \mathrm{rms}$ occurred for a period of $4 \mathrm{~ms}$. At the end of the $4 \mathrm{~ms}$ pulse, the current was off for $13 \mathrm{~ms}$. At the end of this off period, a final current pulse of 420 A rms occurred, lasting $8 \mathrm{~ms}$, at which time the circuit opened between the wire and shorting nail. Placing the current pulse data on the circuit breaker curves of figure 10, it is seen that a circuit breaker trip was likely during the $530 \mathrm{~A}$ pulse and could not occur during the other pulses.

In figure 7,8 , and 9 , the current waves have the lowest amplitudes and the voltage waves have the highest amplitudes. 


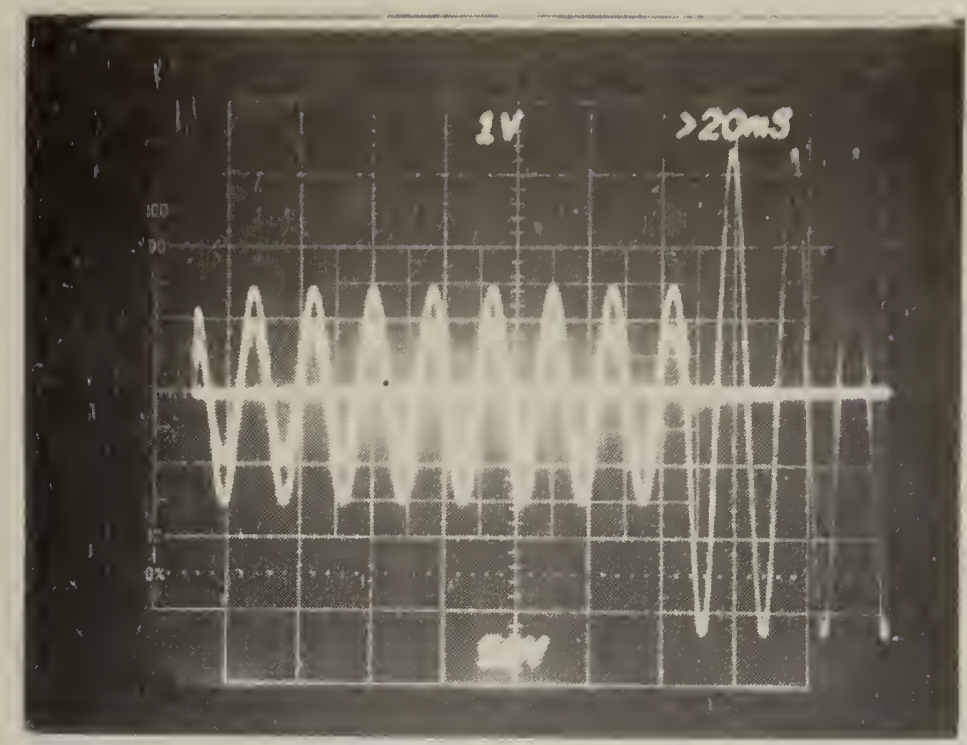
Figure 7. Specimen $\#_{3}$ - circuit breaker
tripped during short circuit

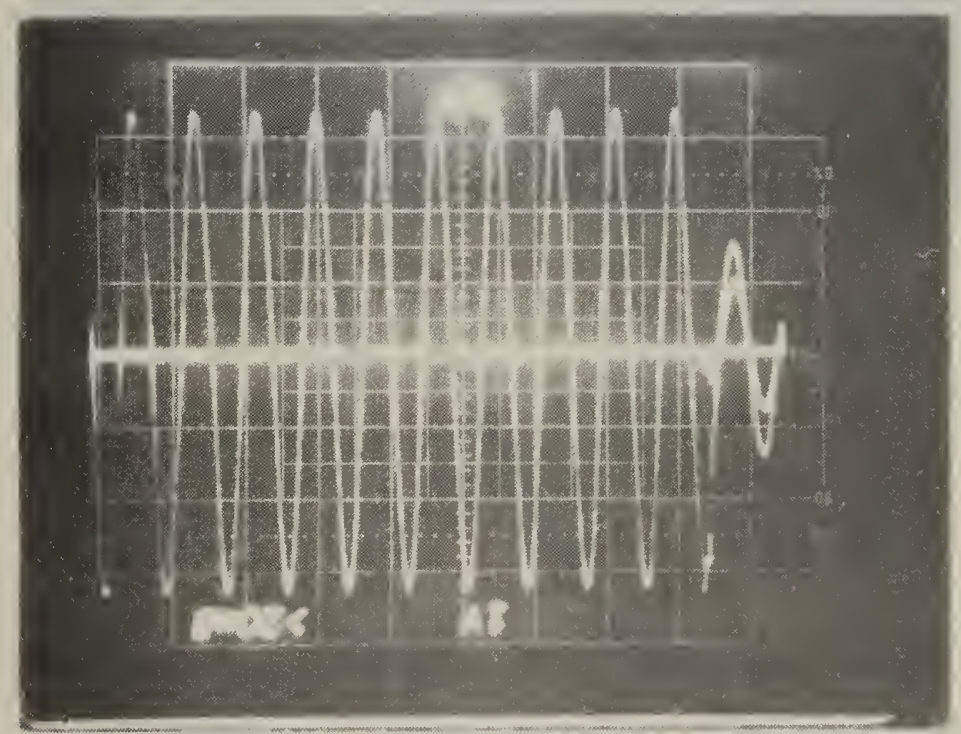

Figure 8. Specimen 非 6 - circuit breaker did not trip during short circuit 


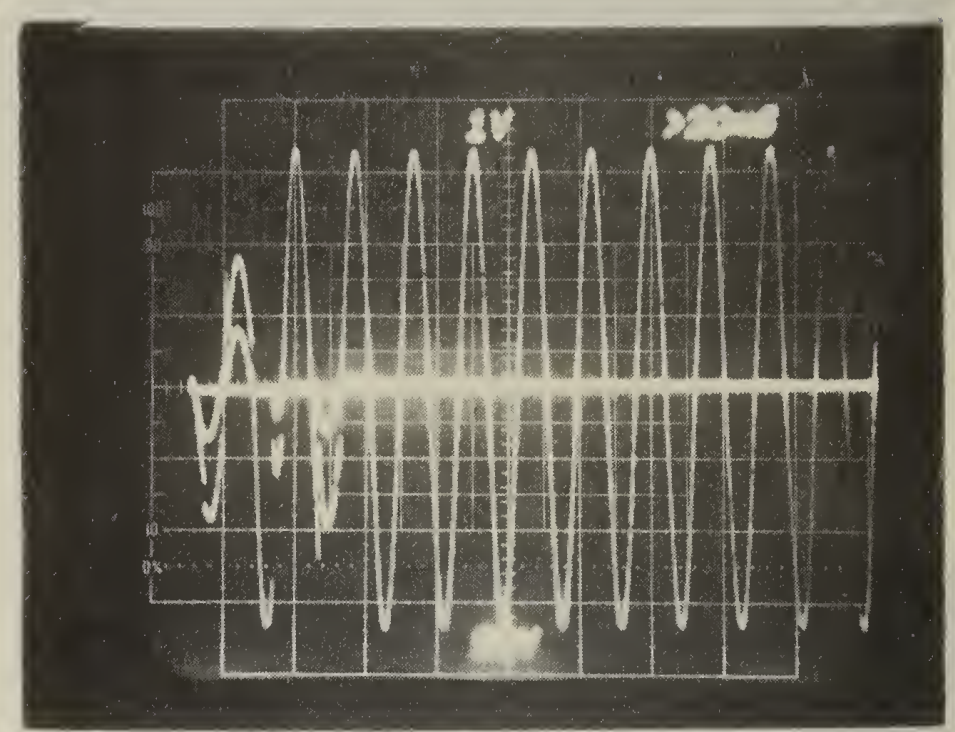

Figure 9. Specimen \#19 - circuit breaker did not trip during short circuit 


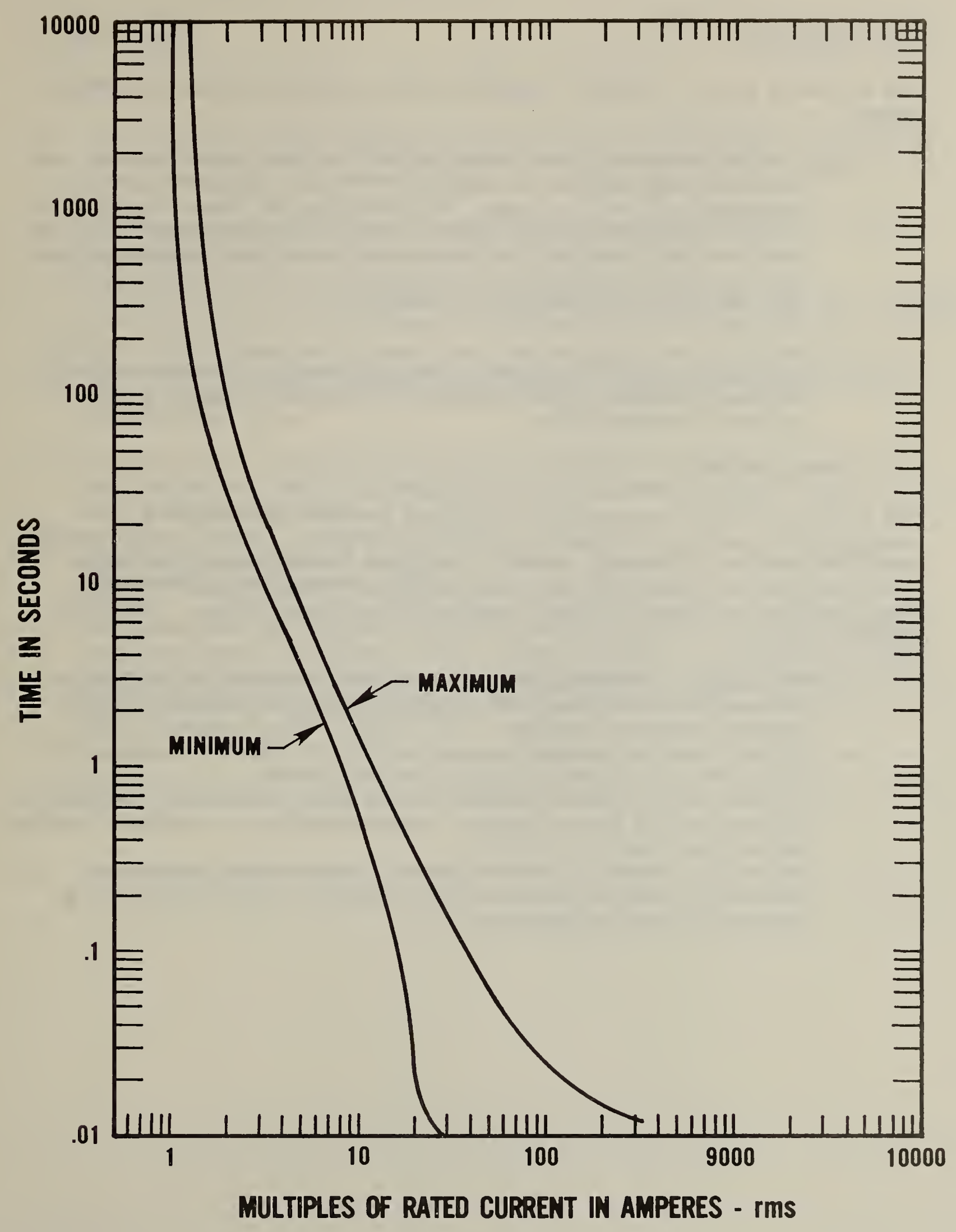

Figure 10. Manufacturer's curves applicable to a 20-ampere circuit breaker 


\section{CONCLUSIONS}

The following can be concluded from this 20 A residential circuit breaker study:

(a) Circuit breakers of the types studied for this report may not trip when carrying currents as large as $28 \mathrm{~A}$ when exposed to ambient temperature of $61^{\circ} \mathrm{F}$ or less. The inability of these circuit breakers to always trip during overcurrents could allow home owners to overload their wiring. Such overloads could cause excessive branch circuit wire temperatures, particularly when the branch circuits are surrounded by thermal insulation [2].

(b) During short circuits which may result from penetration of wiring by nails, circuit breakers of the types studied for this report may not function to interrupt the current and prevent ignition of proximate combustibles.

\section{RECOMMENDATIONS}

The exploratory data presented in this paper indicate a need for a comprehensive study of overcurrent protection devices. Such a study should yield information concerning potential for fire in residential buildings resulting from the inability of overcurrent protection devices to always open circuits and thereby prevent overheating of fixed wiring. The study should include:

a. Development of more meaningful scientific/mathematical principles and models of the functional characteristics of residential overcurrent protection devices.

b. A field study to measure residential circuit breaker temperature during the winter and during the cooling season.

c. A field study of fires alleged to have been electrically induced, to reconstruct and better explain those mechanisms of electrical system failure that result in fires.

d. Laboratory studies of generic types of residential overcurrent devices on a scale large enough to establish statistical data concerning their performance. 


\section{REFERENCES}

[1] Nat1ona1 Electrical Code, 1978, NFPA No. 70-1978.

[2] "Exploratory Study of Temperatures Produced by Self-Heating of Residential Branch Circuit Wiring When Surrounded by Thermal Insulation," Beausoliel, R. W., Meese, W. J., and Galowin, L. S., NBSIR 78-1477, July 1978.

[3] "Molded-case Circuit Breakers and Circuit-breaker Enclosures," UL 489, Underwriter's Laboratories, Inc., November 1, 1972.

[4] "Molded-case Circuit Breakers," Standards Publication No. AB1-1975, National Electrical Manufacturer's Assoc., 155 East 44th St., New York, N.Y. 10017.

[5] "Investigation of Over Current Protection Devices as Affected by Ambient Temperatures," Bulletin of Research, No. 41, July 1948, Underwriter's Laboratories, Inc.

[6] "Procedures for Verifying Performance of Molded-case Circuit Breakers," Publication No. AB2-1976, National Electrical Manufacturer's Assoc., 155 East 44 th St., New York, N.Y. 10017.

[7] "American Electricians' Handbook," John H. Watt Editor, Ninth Edition, McGraw-Hi11 Book Company, 1970.

[8] NBS Monograph 125, "Thermocouple Reference Tables Based on the IPTS-68" by Robert Powe11, William J. Hall, Clyde H. Hyink, Jr. and Larry Sparks, Cryogenics Division, Institute of Basic Standards, NBS and George W. Burns, Margaret G. Scroger, and Harmon H. Plumb, Heat Division, Institute for Basic Standards, NBS, March 1974. 
NBS-114A (REV. 2-8C)

U.S. DEPT. OF COMM.

1. PUBLICATION OR REPORT NO.

BIBLIOGRAPHIC DATA

SHEET (See in struction s)

NBSIR $81-2221$

2. Performing Organ. Report Nod 3. Publication Date

April 1981

4. TITLE AND SUBTITLE

EXPERIMENTALLY DETERMINED PERFORMANCE OF SOME RESIDENTIAL CIRCUIT BREAKERS

5. AUTHOR(S)

Robert W. Beausoliel and William J. Meese

6. PERFORMING ORGANIZATION (If joint or other than NBS, see In structions)

7. Contract Grant No.

NATIONAL BUREAU OF STANDARDS

DEPARTMENT OF COMMERCE

8. Type of Report \& Period Covered

WASHINGTON, D.C. 20234

9. SFONSORING ORGANIZATION NAME AND COMPLETE ADDRESS (Stree, City, Stote, ZIP)

SAME

10. SUPPLEMENTARY NOTES

Document describes a computer program; SF-185, FIPS Software Summary, is attached.

11. ABSTRACT (A 200-word or less factual summary of most significant information. If document includes a slgnificant bibliography or literature survey, mention it here)

Laboratory test results show that at low ambient temperatures some residential-type circuit breakers may not trip at currents up to 140 percent of rated currents. Under some environmental conditions this may lead to wiring temperatures that exceed the limitations specified in the National Electrical Code. The results also show that circuits sometimes open at the point of short circuits before circuit breakers operate. Ignition of combustibles proximate to the point of such short circuits sometimes occurs.

The results indicate the need for a more detailed study of overcurrent protection performance in the field and under laboratory conditions. Also needed are the development of more meaningful scientific/mathematical principles and models on the functional characteristics of circuit breakers.

12. KEY WORDS (Six to twelve entries; alphabetical order; capitalize only proper names; and separate key words by semicolons) branch circuits; circuit breaker; electrical fire; low ambient temperature; trip time.

13. AVAILABILITY

[X] Unlimited

$\square$ For Official Distribution. Do Not Release to NTIS

$\square$ Order From Superintendent of Documents, U.S. Government Printing Office, Washington, D.C. 20402.

X] Order From National Technical Information Service (NTIS), Springfield, VA. 2216I

14. NO. OF PRINTED PAGES

47

15. Price

$\$ 6.50$ 

